\title{
Formation and Taxa of some Wadi Dahab Tributaries Soils, South Sinai, Egypt
}

\author{
Adel A. Elwan \\ Pedology Department, Water Resources and Desert Soils Division, Desert Research Center (DRC), Cairo, 11753, Egypt
}

Received: $15 / 7 / 2018$

\begin{abstract}
Geological parent material is a soil forming factor which controls the particle size distribution (PSD), geochemical characterization, and mineralogical properties. In Wadi Dahab Basin at southeastern Sinai of Egypt, four main tributaries (Al-Ghaib, Zoghra, Abu-Khashab and Um-Ism) and their subtributaries, having different geological parent materials, were selected and mapped. Sixteen pedons containing 51 sediment samples across the slope gradient (1335-9 m) of Wadi Dahab Basin representing all its tributaries and subtributaries were exhaustively analysed for the purposes of: (1) detecting the lithologic discontinuities (LDs) through soil morphology and uniformity indices; (2) recognizing the weathering intensity using the geochemical data; (3) identifying the sediments provenance via heavy mineral distribution; and (4) classifying the soils up to family level. LDs in most pedons revealed sequences of deposition and erosion processes and the heterogeneity of the parent material. The vertical distribution of coarse fragments within a pedon is proposed as a morphologic indicator (as with other clay-free basis indices) to detect LDs in soils. The $\mathrm{Fe}_{2} \mathrm{O}_{3}$ and $\mathrm{Al}_{2} \mathrm{O}_{3}$ were relatively enriched at downslope positions while $\mathrm{SiO}_{2}, \mathrm{MgO}, \mathrm{K}_{2} \mathrm{O}$, and $\mathrm{Na}_{2} \mathrm{O}$ were strongly lost during sediment weathering and soil formation, with the exception of $\mathrm{CaO}$ that was highly affected by $\mathrm{CaCO}_{3}$ content. The heavy minerals characteristics suggest their mixed sources from sandstone, limestone, granites, and metamorphic rocks. The heavy minerals concentration and geochemical oxides in most studied pedons followed the LD set, indicating further approaches for detecting LDs. Pedons from upslope positions were immature sediments and classified as Entisols while pedons from the downslopes of Wadi Al-Ghaib, Wadi Zoghra, and Wadi Dahab's delta were submature sediments and classified as Aridisols. Furthermore, six families were identified across the study area. Indices based on PSD, geochemical, and mineralogical data were evaluated and further implications of the results were discussed in the text.
\end{abstract}

Keywords: Heavy minerals, geochemical data, weathering indices, formation, taxa

\section{INTRODUCTION}

Understanding the formation and provenance of sediments is necessary to effectively implement soil and water conservation measures (Fielding et al., 2018). Soil formation is a competition between pedologic and sedimentologic processes (Giosan et al., 2014; Cámara et al., 2017). Soil is different than sediment. Soil develops from sediment, in sediment (Schaetzl and Anderson, 2005). Knowing how to distinguish the two is critical to the application of soils knowledge. Soil cannot form within solid rock, but can form within the weathered by-products of that rock. Loose, weathered and unconsolidated (parent) materials at the earth's surface are regolith (Schaetzl and Anderson, 2005). Soils develop within regolith under the influence of biota and climate (Fielding et al., 2018). In this process, regolith is eroded, transported, deposited, and most importantly (to soil formation) weathered, which encourages various components of it to be reorganized and translocated internally (Schaetzl and Anderson, 2005). However, few recent studies have focused on evaluating soil uniformity, weathering intensity, and pedogenic processes in arid high mountains (Portes et al., 2016; Fielding et al., 2018). In the current paper, the soil formation is studied through proper estimation of parent material uniformity, weathering intensity, and provenance of the sediments.

For many geologists and pedologists, uniformity of parent material is still in question for contrastingtextured soils in many geomorphic settings (Portes et al., 2016). As a result, identifying lithologic discontinuities (LDs) is crucial to pedogenic interpretation (Cámara et al., 2017). LDs are significant changes in particle size distribution (PSD) throughout the solum or mineralogical composition of the individual horizons or layers from different ages that represent differences in lithology within a regolith (FAO, 2006; Waroszewski et al., 2015). Although the materials may be of the same mineralogy, the contrasting sand sizes result from differences in energy at the time of deposition by water and/or wind (Soil Survey Staff, 2014a). LDs constitute a valuable source of information not only about the time scales of the soil formation itself, but also about the direction of pedogenesis (Schaetzl and Anderson, 2005; Waroszewski et al., 2016). Therefore, the current study examines which the best way to identify the potential presence of LDs within the sandy mantle pedons on the basis of clay-free particle size classes and coarse fragments abundance.

Sediment is an important element in wadis and their connecting waters (Giosan et al., 2014). Weathering intensity and soil formation in high mountain environments are strongly constrained by macroclimatic factors, such as temperature and precipitation (Cámara et al., 2017). Moreover, von Blanckenburg (2005) concluded that the rates of chemical weathering are primarily controlled by erosion rates and geomorphic stability than by temperature or precipitation (Schaetzl and Anderson, 2005). It also strongly dependent on sediment composition of heavy minerals and geochemical oxides (Buggle et al., 2011). The concept of geochemical proxies of element oxides (e.g., weathering indices) relies on the selective removal of soluble and mobile elements from a weathering profile compared to the relative enrichment of rather 
immobile and non-soluble elements (Yang et al., 2004; Buggle et al., 2011). However, pedogenesis does not only mean weathering of minerals and loss of elements, but also mineral transformation and formation of secondary minerals such as, for example, clay minerals or iron oxides (Buggle et al., 2011). There are a number of parameters and various proposals by paleopedologists for meaningful weathering intensity (Schaetzl and Anderson, 2005; Buggle et al., 2011). In the current study, the widely used weathering indices are calculated and evaluated to propose the most proper geochemically based weathering index.

The heavy mineral analysis is one of the most sensitive and effective tools for sediment provenance discrimination (Galovic' and Peh, 2016), and can determine the source terrain and depositional environment of sediments (Mounteney et al., 2018). They are also very useful in evaluating pre-erosional weathering and tectonic history of the source terrain (Nechaev and Isphording, 1993), exploration of minerals, and acquiring information on environmental changes in marine sediments (Mounteney et al., 2018). The processes that determine availability and size of heavy minerals are weathering, mechanical abrasion, hydraulic sorting, and diagenesis (Mounteney et al., 2018). Sediments deposited in drainage Basins are important indicators of the quality of the associated aquatic system, and they inherit the geological characteristics of the catchment during the processes of weathering, erosion, transportation, and deposition (Nechaev and Isphording, 1993). The spatial distribution of sediments in wadis is mainly controlled by variations in the source areas (Galovic' and Peh, 2016). Most heavy minerals are restricted to specific source rocks, and they are sensitive indicators of provenance that can provide crucial provenance and maturity information (Schaetzl and Anderson, 2005).

The current study was conducted in the sediments of Wadi Dahab Basin, west of the Aqaba Gulf, South Sinai, Egypt. The objectives of this study were to: 1) assess the occurrence of LDs and provide the best ways of detecting the heterogeneous nature of soil based on whole soil composition; 2) evaluate the weathering intensity based on geochemical characterization; 3) investigate the distribution of heavy minerals with respect to provenance of the sediments and identify the various depositional areas across the drainage Basin; and finally, 4) classify the soils based on the maturity of the sediments using the USDA Soil Taxonomy (Soil Survey Staff, 2014a).

\section{MATERIALS AND METHODS}

\section{Site description and environmental settings}

The Red Sea at its northern end bifurcates into two linear depressions flanking the Sinai Peninsula, which are Gulf of Suez and Gulf of Aqaba (Salem, 2007) (Fig.1). The current study was conducted in the Wadi Dahab Basin on the coast of Gulf of Aqaba, South Sinai, Egypt (Fig. 1 and Table 1), approximately 75 km northeast of Sharm El-Sheikh city. It is bounded by Wadi Watir Basin to the north, Wadi Al-Arish Basin to the northwest, Wadi Kid and Sharm Al-Sheikh city to the south, and Gulf of Aqaba to the east. It is situated between latitudes $28^{\circ} 20^{\prime \prime}$ and $28^{\circ} 55^{\prime \prime} \mathrm{N}$; and longitude $34^{\circ} 3^{\prime \prime}$ and $34^{\circ} 33^{\prime \prime}$ E. The Wadi Dahab drainage Basin occupies a total area of about $1850 \mathrm{~km}^{2}$, of which 217 $\mathrm{km}^{2}$ as Wadi streams from upstreams to the Wadi Dahab's delta (Table 1). It is one of the largest drainage Basins in eastern Sinai, which drains into the Gulf of Aqaba of Red Sea. Dahab region is a home to many tourism destinations; with tourism as the major source of Egypt's national income. It is currently under consideration for reinvigorated agricultural development.

Four main tributaries and ten subtributaries of Wadi Dahab Basin (Table 1), representing different geological parent materials, were chosen, delineated, and mapped using ArcGIS software (Figs. 2, 3 and Table 1). The main tributaries are Wadi Al-Ghaib, Wadi Zoghra, Wadi Abu-Khashab, and Wadi Um-Ism. Wadi Zoghra stream is the longest $(51 \mathrm{~km})$, the largest (42 $\mathrm{km}^{2}$ ), and the highest (1335 $\mathrm{m}$ above sea level) tributary of Wadi Dahab (Table 1) followed by Wadi Al-Ghaib stream (22 km length; $16 \mathrm{~km}^{2}$ area) that is situated in the north. Wadi Al-Ghaib consists of five subtributaries, from up to down: Wadi Abu-Gardat (6 $\mathrm{km} ; 4 \mathrm{~km}^{2}$ ), Wadi Al-Gibby (18 km; $\left.21 \mathrm{~km}^{2}\right)$, Wadi Hadaba $\left(3.5 \mathrm{~km} ; 3 \mathrm{~km}^{2}\right)$, Wadi Um-Markha (4 km; 2 $\mathrm{km}^{2}$ ), and Wadi Abu-Rowis $\left(8.5 \mathrm{~km} ; 4 \mathrm{~km}^{2}\right)$. Wadi Zoghra is the western tributary of Wadi Dahab and has three subtributaries: Wadi Mareikh $\left(8 \mathrm{~km} ; 4 \mathrm{~km}^{2}\right)$ ), Wadi Nasab (27 km; $\left.35 \mathrm{~km}^{2}\right)$, and Wadi Al-Hamam (25 $\left.\mathrm{km} ; 10 \mathrm{~km}^{2}\right)$. Meanwhile Wadi Abu-Khashab (16 km; $11 \mathrm{~km}^{2}$ ) is located in the south and has only two subtributaries which are Wadi Maaian $\left(20 \mathrm{~km} ; 31 \mathrm{~km}^{2}\right)$ and Wadi Shuki $\left(9 \mathrm{~km} ; 4 \mathrm{~km}^{2}\right.$ ) (Table 1). By contrast, Wadi Um-Ism is the nearest tributary to the Wadi Dahab's delta and the shortest and smallest tributary (6 $\mathrm{km} ; 3 \mathrm{~km}^{2}$ ) of Wadi Dahab, which doesn't have any subtributary (Table 1). Wadi Dahab flows from the northwest through subtributaries of Wadi Al-Ghaib and Wadi Zoghra to the southwest through Wadi AbuKhashab and Wadi Um-Ism into the Gulf of Aqaba. All these wadis (tributaries and subtributaries) pour into the master stream of Wadi Dahab $\left(15 \mathrm{~km} ; 27 \mathrm{~km}^{2}\right)$ forming a large fan called a delta of Wadi Dahab at downstream of the drainage Basin (Figs. 1, 2, 3 and Table 1). This delta is one of the most major submarine fans developed on eastern Sinai during periods of low sea-level by transporting the sediments gravity flows across the slope gradient to the Basin floor (Youssef et al., 2010). Elevations above sea level within $1850 \mathrm{~km}^{2}$ Wadi Dahab Basin study area range from $9 \mathrm{~m}$ in the Wadi Dahab's delta at lowland to $1335 \mathrm{~m}$ in the upper portion of Wadi Zoghra at upland (Table 1 and Fig. 1).

The study area has generally an arid climate with quite significant rainfall intensity (Salem, 2007). Although it is located in an arid region, the Dahab Basin infrequently receives flash flood water from much of southern and central Sinai causing catastrophic effects on existing infrastructure which make a great threat to the life and property of Dahab city located in the delta (Youssef et al., 2010). The mean annual soil 
temperature ranges from $23^{\circ} \mathrm{C}$ to $27^{\circ} \mathrm{C}$ (Salem, 2007). As per the meteorological conditions of South Sinai, flood events are not frequent, but severe (Youssef et al., 2010). The maximum recorded value reached up to 159 million $\mathrm{m}^{3} /$ storm (Issawi et al., 1998). In this accord, three dams are constructed across the slope gradient of Wadi Al-Ghaib to reduce the flood risks on Dahab city; one dam at the Wadi Al-Gibby mouth and two dams at the midstream and downstream of Wadi Al-Ghaib. Based on the communication with the local farmers and government, the check dams were built in 1999 and destroyed by the extreme floods twice in 2004 and 2010 .

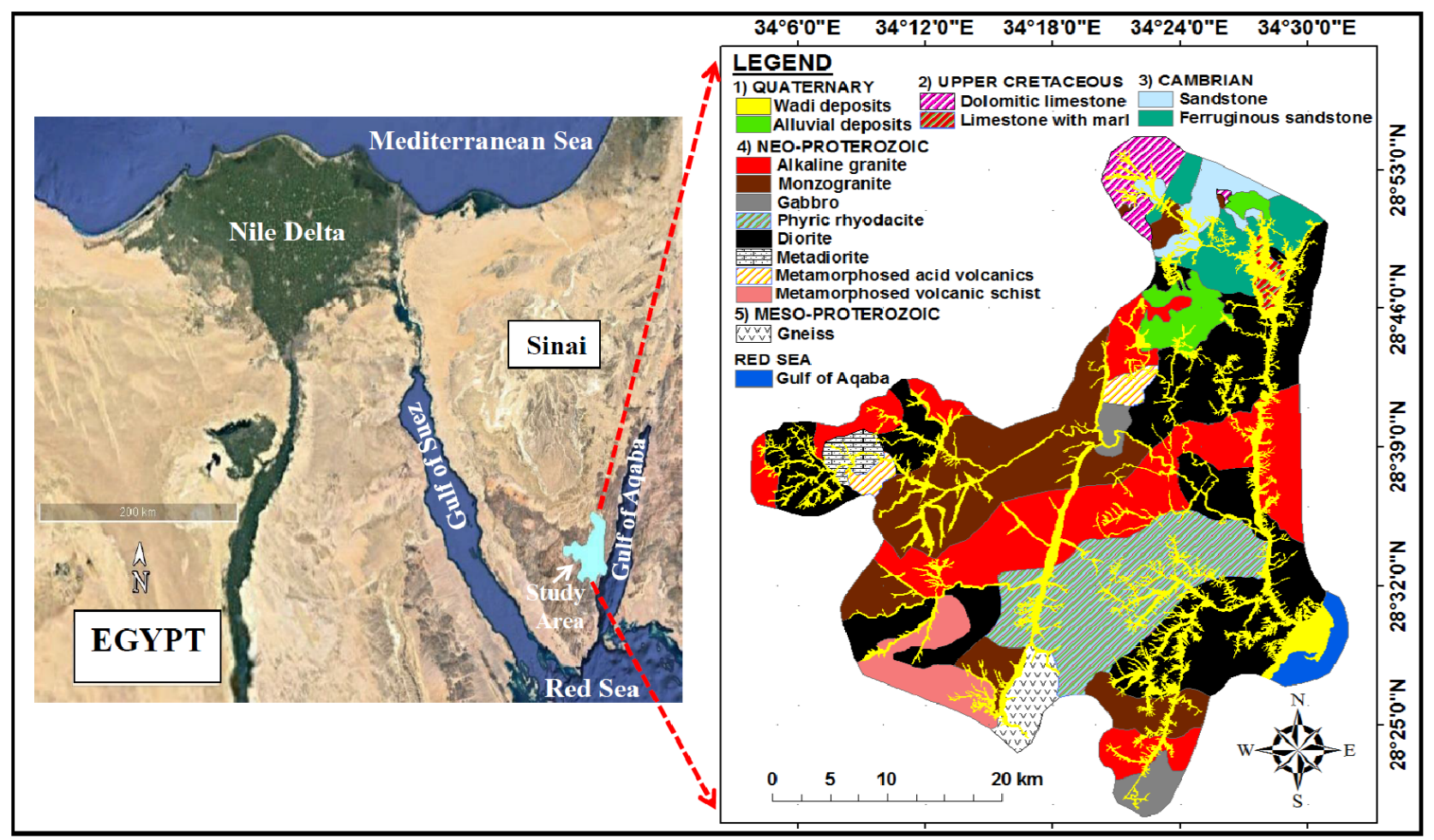

Fig. (1): Location map of Wadi Dahab study area located in southeastern Sinai of Egypt. Right panel is a geological map denoting differences in lithological terrain across the Wadi Dahab Basin

Table (1): Description of Wadi Dahab drainage Basin ${ }^{*}$ and its main tributaries and subtributaries

\begin{tabular}{|c|c|c|c|c|c|}
\hline Mainstream & Main tributaries & Subtributaries & Length & Area & Elevation range $(\mathrm{m}$; \\
\hline \multirow[t]{16}{*}{ Wadi Dahab stream } & 4 & 10 & 15 & 27 & 231-9 \\
\hline & Wadi Al-Ghaib: & 5 & 22 & 16 & $453-231$ \\
\hline & & Wadi Abu-Gardat & 6 & 4 & $731-547$ \\
\hline & & Wadi Al-Gibby & 18 & 21 & $901-543$ \\
\hline & & Wadi Hadaba & 3.5 & 3 & $685-503$ \\
\hline & & Wadi Um-Markha & 4 & 2 & $813-481$ \\
\hline & & Wadi Abu-Rowis & 8.5 & 4 & $885-330$ \\
\hline & Total & & 62 & 50 & \\
\hline & Wadi Zoghra: & 3 & 51 & 42 & 1335-191 \\
\hline & & Wadi Mareikh & 8 & 4 & $741-535$ \\
\hline & & Wadi Nasab & 27 & 35 & $977-509$ \\
\hline & & Wadi Al-Hamam & 25 & 10 & $801-291$ \\
\hline & Total & & 111 & 91 & \\
\hline & Wadi Abu- & 2 & 16 & 11 & $1055-98$ \\
\hline & & Wadi Maaian & 20 & 31 & $670-251$ \\
\hline & & Wadi Shuki & 9 & 4 & $577-175$ \\
\hline & Total & & 45 & 46 & \\
\hline & Wadi Um-Ism & - & 6 & 3 & $275-61$ \\
\hline \multicolumn{2}{|c|}{ Total for Wadi Dahab's streams } & - & 239 & 217 & $1335-9$ \\
\hline
\end{tabular}

* Total area of Wadi Dahab drainage Basin:

$1850 \mathrm{~km}^{2}$ 
Geological mapping of the south Sinai (Geological Survey of Egypt, 1994) indicates different lithologies along Wadi Dahab Basin varying in age from Quaternary to Precambrian (Fig. 1). South Sinai is deeply dissected by wadis that are carved intermittently during a long time spanning the Phanerozoic and Precambrian ages (Badawy and Horvath, 1999). Wadis break surfaces of the plateau and mountains into a series of detached ridges and hummocks (Issawi et al., 1998). The northwestern portion of the study area is dominantly covered with Neoproterozoic era rocks (e.g., granite, gabbro, diorite, and metamorphic rocks) (Badawy and Horvath, 1999). Sedimentary rocks (e.g., sandstone and limestone) of upper Cretaceous and Cambrian ages are located in the north of the Basin while the rest of the Basin is covered with Precambrian rocks (igneous and metamorphic rocks) (Issawi et al., 1998). Quaternary period of Cenozoic era sediments (e.g., Wadi deposits and alluvial deposits) covered the Wadi floors of the different streams (Fig. 1). Exposed rocks of the Precambrian shield includes a variety of igneous and metamorphic rocks (Issawi et al., 1998). Oldest Phanerozoic sediments in the Basin are represented by the Cenozoic sandstones unconformably overlain by a Mesozoic thick section which consists of clastic sediments at base grading upward into carbonates with shale interbeds followed by a thick chalk unit at the top (Geological Survey of Egypt, 1994). Pleistocene and Holocene are represented by shales whereas the Eocene succession consists of a limestone unit with chert bands. Quaternary sediments are very well developed in the study area (Issawi et al., 1998).

\section{Sampling scheme and laboratory methods}

Sixteen pedons were distributed on the catenas of the tributaries and subtributaris along the environmental gradient (1335-9 m) of Wadi Dahab Basin from the north at upslope in the Wadi Abu-Gardat (P1) to the south at downslope in the Wadi Dahab's delta (P16) (Figs. 2 and 3). From which, eleven pedons were sampled from upslope positions (P1, P2, P3, P4, P5, P6, $\mathrm{P} 8, \mathrm{P} 9, \mathrm{P} 10, \mathrm{P} 12$, and $\mathrm{P} 13)$ while other five pedons (P7, $\mathrm{P} 11, \mathrm{P} 14, \mathrm{P} 15$, and P16) were chosen from downslope positions. The studied pedons were collected as follows: seven pedons from Wadi Al-Ghaib and its subtributaries (P1 from Wadi Abu-Gardat, P2 from dam-controlled watershed of Wadi Al-Gibby, P3 from Wadi Hadaba, P4 from Wadi Um-Markha, P5 from Wadi Abu-Rowis, P6 from the midstream of Wadi Al-Ghaib behind the check dam 2, and P7 from dam-controlled watershed of Wadi Al-Ghaib) (Fig. 2); four pedons from Wadi Zoghra and its subtributaries (P8 from Wadi Mareikh, P9 from Wadi Nasab, P10 from Wadi Al-Hamam, and P11 from Wadi Zoghra bottom) (Fig. 2); three pedons from Wadi Abu-Khashab and its subtributaries (P12 from Wadi Maaian, P13 from Wadi Shuki, and P14 from Wadi Abu-Khashab downstream) (Fig. 3); P15 from Wadi Um-Ism; and P16 from Wadi Dahab's delta at downslope of the toposequence (Fig. 3).

After sampling sites were identified, pedons were dug. Physical setting and profile descriptions were conducted according to the Soil Science Division Staff
(2017) and Schoeneberger et al. (2012). Pedon faces were first sketched and photographed (Figs. 4 and 5) and then horizons/layers were sampled. Fifty-one sediment samples were collected from the studied sixteen pedons for different analyses. Samples were airdried and sieved to remove coarse fragments $(>2 \mathrm{~mm})$. Field descriptions estimated the volume of rock fragments for the various size classes (Soil Science Division Staff, 2017). Stones and boulders of the most representative rocks were handpicked from each pedon to determine the rocks that comprise the parent material. The air-dried soil samples were crushed and sieved to $<$ $2 \mathrm{~mm}$. A modified Wentworth size fractionation scheme described by Walter et al. (1978) was used to determine the sand fractionation texture. An additional break at $63-\mu \mathrm{m}$ was made so that USDA textural classes could be identified. The remaining fine earth fraction was analyzed in the laboratory. Particle size distribution (PSD) was determined by pipette with prior $\mathrm{H}_{2} \mathrm{O}_{2}$ pretreatment to remove organic matter for pedon horizons/layers (Sheldrick and Wang, 1993). Sand separates were determined by dry sieving the sand fraction (Soil Survey Staff, 2014b). All particle size analyses were conducted on a clay-free basis, which excludes pedogenic (mobile) clay from the baseline skeletal fraction inherited from the parent material so that potential lithologic discontinuities (LDs) are not obscured (Schaetzl and Anderson, 2005). Calcium carbonate and gypsum contents were determined as per the standard procedures suggested by Soil Survey Staff (2014b). Sediment samples were analyzed for geochemical element oxides using X-ray fluorescence spectrometer in weight percentages, following Sheldon et al. (2002), for the use in chemical weathering analyses. The element oxides, determined in soil samples, included silica $\left(\mathrm{SiO}_{2}\right)$, titania $\left(\mathrm{TiO}_{2}\right)$, alumina $\left(\mathrm{Al}_{2} \mathrm{O}_{3}\right)$, ferric oxide $\left(\mathrm{Fe}_{2} \mathrm{O}_{3}\right)$, manganese oxide $(\mathrm{MnO})$, magnesium oxide $(\mathrm{MgO})$, silicate $\mathrm{Ca}$ (calcium oxide) $(\mathrm{CaO})$, sodium oxide $\left(\mathrm{Na}_{2} \mathrm{O}\right)$, potassium oxide $\left(\mathrm{K}_{2} \mathrm{O}\right)$, phosphorus pentoxide $\left(\mathrm{P}_{2} \mathrm{O}_{5}\right)$, and chromium oxide $\left(\mathrm{Cr}_{2} \mathrm{O}_{3}\right)$.

\section{Uniformity indices}

The detection of lithologic discontinuities (LDs) was based on the nonuniformity of the parent material (Schaetzl and Anderson, 2005). Field and laboratory data sets were evaluated in depth function as a visual estimation of rock fragments which used in this paper to detect the LDs. The difference in the grain size of soil (silt and sand) was studied using the uniformity value index (UV1) (Cremeens and Mokma, 1986) (Formula 1). The UV1 index compares particle size data from the horizon/layer above.

$\mathrm{UV1}=\frac{[(\mathrm{Si}+\mathrm{VFS}) /(\mathrm{S}-\mathrm{VFS})] \text { in overlaying horizon/layer }}{[(\mathrm{Si}+\mathrm{VFS}) /(\mathrm{S}-\mathrm{VFS})] \text { in overlaying horizon/layer }}-1(1)$

Where UV1 is a uniformity value index of Cremeens and Mokma (1986). Si is silt content, Vfs is very fine sand content, and $\mathrm{S}$ stands for whole sand content.

Another method was suggested by Kowalska et al. (2016) for calculation of uniformity values (UV2) that considers the whole granulometric fraction in the 
soil (clay, silt, and sand) (Formula 2). In the current study, this method is applied and tested against the UV1 method.

uv2 $=\frac{[(C+S i) /(S)] \text { in owerlaying horizon } / \text { layer }}{[(C+S i) /(S)] \text { in overlaying horizon } / \text { layer }}-1$

Where UV2 is uniformity value index of Kowalska et al. (2016), $\mathrm{C}$ is clay content, $\mathrm{Si}$ is silt content, and $\mathrm{S}$ stands for sand content.
The closer the UV1 or UV2 is to zero, the more likely that the two horizons or layers in a pedon formed from similar parent materials. Values higher than 0.60 clearly indicate the presence of a lithologic discontinuity (LD) and nonuniformity of the parent material (Cremeens and Mokma, 1986; Schaetzl and Anderson, 2005).

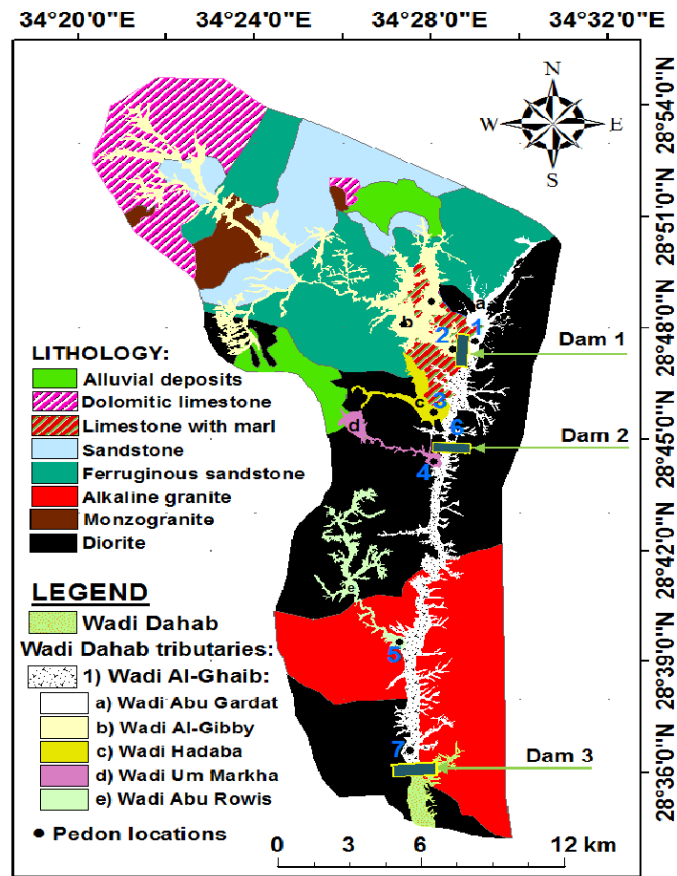

$34^{\circ} 6^{\prime} 0^{\prime \prime E} \quad 34^{\circ} 12^{\prime} 0^{\prime \prime E} \quad 34^{\circ} 18^{\prime} 00^{\prime E} \quad 34^{\circ} 24^{\prime} 0^{\prime \prime E} \quad 34^{\circ} 30^{\prime} 0^{\prime \prime E}$

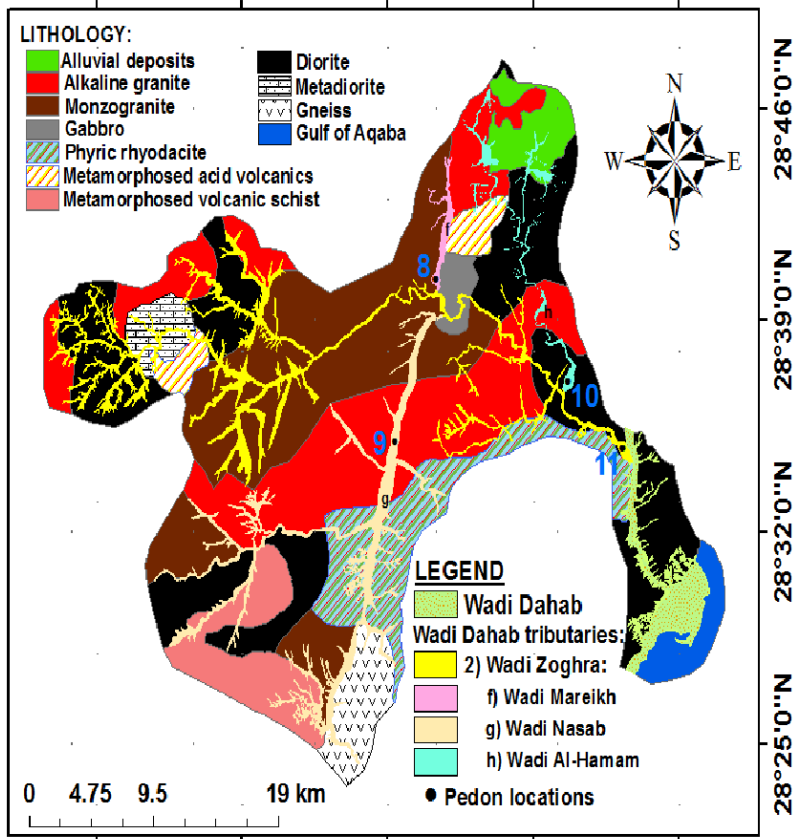

Fig. (2): Maps of Wadi Al-Ghaib and Wadi Zoghra and their subtributaries showing the sampling pedons (black dots). Left panel shows the location of the Wadi Al-Ghaib and its subtributaries. Right panel shows the location of the Wadi Zoghra and its subtributaries location

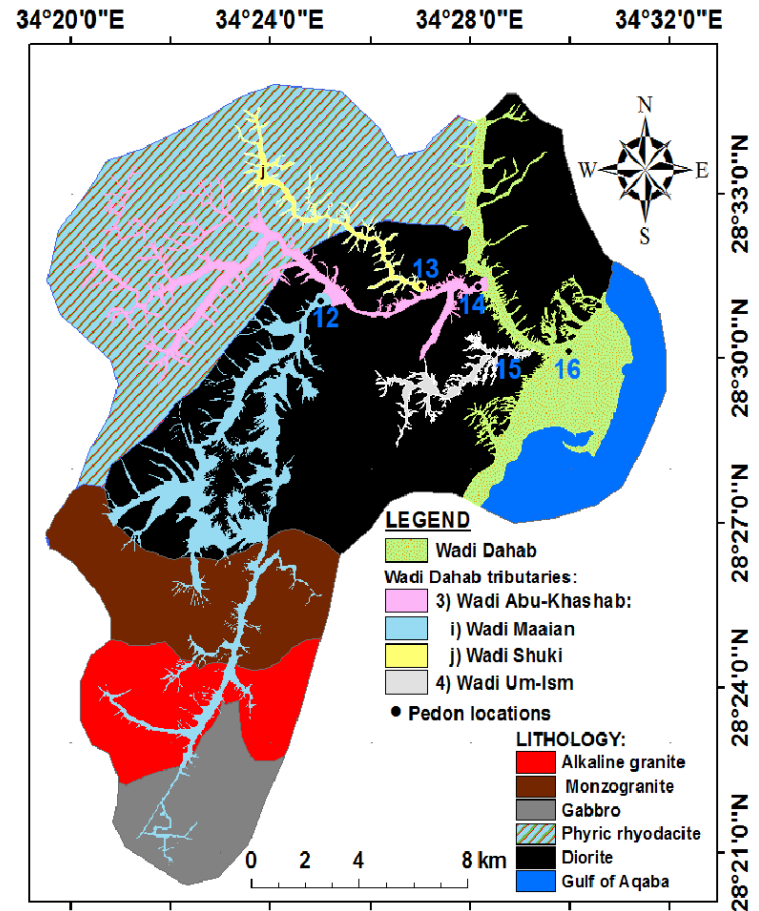

Fig. (3): Sketch map of wadis Abu-Khashab and UmIsm showing the pedon sampling sites (black dots) and their lithology structure

\section{Geochemical indices}

The principal assumption in formulating chemical weathering indices is that the behavior of chemical elements is controlled solely by the degree of weathering. More specifically, it is expected that, as the intensity of weathering increases: (a) certain major oxides, including $\mathrm{Al}_{2} \mathrm{O}_{3}, \mathrm{Fe}_{2} \mathrm{O}_{3}$ and $\mathrm{TiO}_{2}$, considered as immobile, remain constant; and (b) $\mathrm{SiO}_{2}, \mathrm{Na}_{2} \mathrm{O}, \mathrm{K}_{2} \mathrm{O}$, $\mathrm{CaO}$ and $\mathrm{MgO}$, considered as mobile, decrease (Düzgören-Aydin et al., 2002). To determine the extent of sediments weathering, the common established $\mathrm{Na}$ type indices for feldspar or plagioclase weathering were calculated. The weathering indices are the chemical index of alteration (CIA) (Nesbitt and Young, 1982), the chemical index of weathering (CIW) (Harnois, 1988), and the chemical proxy of alteration (CPA) (Buggle et al., 2011). CIA index represents a ratio of predominantly immobile $\mathrm{Al}_{2} \mathrm{O}_{3}$ to the mobile cations $\mathrm{Na}^{+}, \mathrm{K}^{+}$and $\mathrm{Ca}^{2+}$ given as oxides (Equation 3 ).

$$
\mathrm{CIA}=\left[\left(\mathrm{Al}_{2} \mathrm{O}_{3}\right) /\left(\mathrm{Al}_{2} \mathrm{O}_{3}+\mathrm{CaO}+\mathrm{Na}_{2} \mathrm{O}+\mathrm{K}_{\mathbf{2}} \mathrm{O}\right)\right] \times \mathbf{1 0 0}
$$

In 1988, Harnois modified the CIA. He emphasized that $\mathrm{K}^{+}$should not be used in weathering indices, since it shows no consistent behavior during weathering, being either enriched in the residue, if weathering is weak, or depleted under more intense weathering conditions. Thus, 
$\mathrm{K}$ was eliminated from the CIA and the resulting index of feldspar weathering was reported as CIW (Equation 4) or K-free CIA (Harnois, 1988).

$$
\mathrm{CIW}=\left[\left(\mathrm{Al}_{2} \mathrm{O}_{3}\right) /\left(\mathrm{Al}_{2} \mathrm{O}_{3}+\mathrm{CaO}+\mathrm{Na}_{2} \mathrm{O}\right)\right] \times 100
$$

CPA (Ca-free) (Equation 5) is a modified version of the classical CIW. Regarding the main host minerals of $\mathrm{Na}$ and $\mathrm{Al}$ in sediments, it should indicate feldspar, especially plagioclase weathering.

$$
\mathrm{CPA}=\left[\left(\mathrm{Al}_{2} \mathrm{O}_{3}\right) /\left(\mathrm{Al}_{2} \mathrm{O}_{3}+\mathrm{Na}_{2} \mathrm{O}\right)\right] \times \mathbf{1 0 0}
$$

The CIA, CIW, and CPA indices have values in a range of $1-100 \%$, where a higher value indicates more intense chemical weathering. According to Nesbitt and Young (1982), CIA values of $<55 \%$ indicate the occurrence of physical weathering with no chemical weathering while CIA values of $>55 \%$ indicate the occurrence of chemical weathering with different degrees.

\section{Microscopic methods}

To determine the mineral composition of heavy and light mineral associations, all samples were sieved to the $63-250 \mu \mathrm{m}$ size fraction. This fraction was selected for the analysis because it includes all virtual mineral species in proportions representative for the bulk sample. The standard procedures of Mange and Maurer (1992) and Mange and Wright (2007) were applied to separate and prepare the heavy minerals in the 51 samples from studied pedons. Each sediment sample was first treated with $30 \%$ hydrogen peroxide to remove the organic matter. It was then decalcified with $20 \%$ hydrochloric acid. The heavy minerals were separated from this fraction using bromoform $\left(\mathrm{CHBr}_{3}\right)$ at a density of $2.85-2.88 \mathrm{~g} \mathrm{~cm}^{-3}$. The heavy minerals were mounted on glass slides and identified using a petrographic (polarizing) microscope with the counting results expressed as percentages. Canada balsam was used as the mounting medium. The abundance of each non-opaque mineral was calculated as a percentage of the total grains counted for each sample.

To identify the source rock of the sediments, the provenance-sensitive heavy mineral ratios are calculated. These are the Garnet-Zircon index (GZi) and the RutileZircon index (RZi). Moreover, to discriminate the maturity of the sediments, the Tourmaline-Rutile index (ZTR) index was determined. GZi and RZi indices are consistent provenance indicators, and produced by Morton and Hallsworth (1994) while the ZTR index is the mineralogical maturity of the heavy mineral assemblages of the sediments, and suggested by Hubert (1962). The GZi is the ratio of garnet to total garnet plus zircon, expressed as a percentage (Equation 6). Garnets are relatively stable heavy minerals. It is mainly derived from metamorphic rocks and can also occur in magmatic rocks.

$$
\text { GZi }=[(\text { garnet }) /(\text { garnet }+ \text { zircon })] \times 100
$$

Whereas the $\mathrm{RZi}$ is the ratio of rutile to total rutile plus zircon, expressed as a percentage (Equation 7). Zircon mainly crystallises in granitic and other plutonic rocks while rutile consisting of titanium dioxide $\left(\mathrm{TiO}_{2}\right)$ forms predominantly in metamorphic rocks (Mange and Maurer, 1992; Mange and Wright, 2007).

$$
\mathbf{R Z i}=[(\text { rutile }) /(\text { rutile }+ \text { zircon })] \times \mathbf{1 0 0}
$$

Moreover, the ZTR maturity index is the percentage of the combined zircon, tourmaline, and rutile among the total non-opaque heavy minerals (Equation 8). The three minerals have high mechanical and chemical stability to wear and tear. Less resistant unstable minerals are dissolved down when the maturity of the sediments increases. Most resistant minerals remain almost unchanged and their relative abundance to their counterparts in sediment increases. This is the reason why the percentage of these resistant minerals cam express the sediments maturity.

\section{$\mathrm{ZTR}=[($ zircon + tourmaline + rutile $) /(\Sigma$ non-opaques $)] \times 100(8)$}

All pedons of the Wadi Dahab drainage Basin were classified up to family level as per USDA Soil Taxonomy (Soil Survey Staff, 2014a).

\section{RESULTS}

\section{Morphological and physicochemical characteristics}

Field morphological attributes, physicochemical data, and uniformity indices for all pedons are presented in Table (2). All pedons under investigation are clearly vertically differentiated for different layer sequences in terms of their morphology and texture (Figs. 4 and 5). Moist colors of all studied pedons range from pinkish white (7.5YR 8/2) to reddish yellow (7.5YR 6/6, 6/8, 7/6, $7 / 8,8 / 6)$. Although the soil matrix has only a hue of $7.5 \mathrm{YR}$, it has values of 6,7 , or 8 and different chromas that widely ranged from 1 to 8 . Most pedons derived from ferruginous sandstone have reddish colored uppermost horizons (Table 2) while other pedons are usually pinkish. All pedons showed a trend of increasing soil depth with decreasing altitude. The deepest pedons were located at the lowest positions of Wadi Dahab Basin (P6, P7, P11, and P16) (Figs. 4e,f and 5c,h). On the other hand, most pedons located at upper positions such as Wadi Abu-Gardat and Wadi Al-Gibby received more colluvial material and are shallower (Fig. 4c,d). Sediments of pedons 2, 6, and 7 were trapped by different dams (Fig. 4a,b), suggesting moderately $(100 \mathrm{~cm})$ to very deep $(175-185 \mathrm{~cm})$ thickness regolith (Fig. 4d,e,f). Pedon 7 at the dam-controlled watershed of Wadi Al-Ghaib is similar to P11 at downsteam of Wadi Zoghra in their morphology and PSD. Their effective depth of regolith is varies from deep $(140 \mathrm{~cm})$ in P11 to very deep $(175 \mathrm{~cm})$ in P7 with well-drained and reddish yellow horizons. Most horizons of P7 have loose to very friable consistence, whereas the lower horizons of Wadi Zoghra were firm or very firm in moist consistence. The evidence of reduced soil matrices was found within these pedons (P7 and P11) and their horizons exhibited common, faint, finely disseminated iron depletion. Redox concentrations in the lower horizons of these pedons appeared in the form of oxidized iron $\left(\mathrm{Fe}^{+3}\right)$ masses in the matrix around depletions. By contrast, the carbonate effervescence was absent in Wadi Zoghra and higher in Wadi Al-Ghaib as finely disseminated carbonates or masses indicative for their origin from upper limestone plateau. All regolith layers present massive to single grain as structureless, which are neither plastic nor sticky. 
Table (2): Some field morphological and physicochemical characteristics of sampled pedons in Wadi Dahab and its tributaries

\begin{tabular}{|c|c|c|c|c|c|c|c|c|c|c|c|c|c|c|c|c|c|c|c|}
\hline \multirow{2}{*}{ Pedon ID } & \multirow{2}{*}{$\begin{array}{c}\text { Depth } \\
\text { (cm) }\end{array}$} & \multirow{2}{*}{$\begin{array}{l}\text { Layer } \\
\text { thickness } \\
(\mathrm{cm})\end{array}$} & \multirow{2}{*}{ Color $^{\dagger}$} & \multirow{2}{*}{$\underset{\text { Seatures }}{\text { Special }^{\ddagger}}$} & \multirow{2}{*}{ Boundary ${ }^{\S}$} & \multirow{2}{*}{$\begin{array}{c}\text { Gypsum } \\
(\%)\end{array}$} & \multirow{2}{*}{$\begin{array}{c}\mathrm{CaCO}_{3} \\
(\%)\end{array}$} & \multirow{2}{*}{$\begin{array}{l}\text { Gravel } \\
\left(\mathrm{g} \mathrm{kg}^{-1}\right)^{\top}\end{array}$} & \multicolumn{3}{|c|}{ Fine earth $\left(\mathrm{g} \mathrm{kg}^{-1}\right)^{4}$} & \multicolumn{5}{|c|}{ Sand separates $\left(\mathrm{g} \mathrm{kg}^{-1}\right)^{4}$} & \multirow{2}{*}{$\begin{array}{l}\text { USDA } \\
\text { Textur }\end{array}$} & \multirow{2}{*}{$\mathrm{UV1}^{\#}$} & \\
\hline & & & & & & & & & $\mathrm{S}$ & $\mathrm{Si}$ & $\mathrm{C}$ & vCS & CS & MS & FS & VFS & & & UV2 ${ }^{*}$ \\
\hline P1-Wadi & & $15-30$ & $7.5 \mathrm{YR} 8 / 6$ & & $\overline{A, W}$ & 0 & 4.1 & 150 & 749 & 215 & 36 & 129 & 98 & $\overline{142}$ & 215 & 165 & LS & 0.95 & $\overline{0.52}$ \\
\hline Abu-Gardat & 100 & $30-55$ & $7.5 \mathrm{YR} 8 / 4$ & SL & $\mathrm{A}, \mathrm{S}$ & 0 & 2.5 & 635 & 819 & 138 & 43 & 195 & 315 & 99 & 109 & 101 & LCOS & -0.62 & -0.41 \\
\hline & & $30-40$ & $7.5 \mathrm{YR} 8 / 6$ & -- & -- & 0 & 3.6 & 75 & 728 & 231 & 41 & 132 & 135 & 105 & 139 & 217 & COSL & -- & -- \\
\hline P2-Wadi & & $50-60$ & $7.5 \mathrm{YR} 7 / 8$ & SL & $\mathrm{A}, \mathrm{W}$ & 0 & 17.4 & 835 & 716 & 224 & 60 & 121 & 124 & 133 & 127 & 211 & SL & 0.75 & -0.28 \\
\hline Al-Gibby & 125 & $15-45$ & 7.5 YR7/6 & LN & $\mathrm{A}, \mathrm{S}$ & 0 & 15.6 & 270 & 644 & 230 & 126 & 238 & 185 & 98 & 65 & 58 & COSL & -0.03 & $\begin{array}{l}-0.200 \\
-0.03\end{array}$ \\
\hline (Dam 1) & & $30-50$ & 7.5YR7/6 & -- & -- & 0 & 14.7 & 30 & 637 & 215 & 148 & 208 & 139 & 107 & 111 & 72 & COSL & -- &.-- \\
\hline & & 20 & $7.5 \mathrm{YR} 8 / 3$ & $\overline{--}$ & $\bar{A}, \mathrm{~S}$ & 0 & 9.8 & 175 & 864 & 92 & 44 & 305 & 209 & 197 & 139 & 14 & LCOS & 0.03 & 0.37 \\
\hline P3-Wadi & 55 & 25 & $7.5 Y R 8 / 4$ & SL & $\mathrm{A}, \mathrm{S}$ & 0 & 9.5 & 360 & 897 & 69 & 34 & 294 & 164 & 266 & 138 & 35 & $\cos$ & 0.20 & 0.03 \\
\hline Hadaba & & 10 & $7.5 \mathrm{YR} 8 / 4$ & -- & -- & 0 & 8.6 & 355 & 900 & 39 & 61 & 295 & 289 & 124 & 145 & 47 & $\cos$ & -- & -- \\
\hline P4-Wadi & 40 & 25 & $7.5 \mathrm{YR} 8 / 4$ & SL & $\mathrm{A}, \mathrm{S}$ & 0 & 3.9 & 450 & 878 & 98 & 24 & 334 & 215 & 195 & 89 & 45 & $\mathrm{COS}$ & 0.02 & -0.24 \\
\hline Um-arkha & 40 & 15 & $7.5 \mathrm{YR} 8 / 3$ & -- & -- & 0 & 6.5 & 360 & 845 & 129 & 26 & 298 & 315 & 102 & 119 & 11 & LCOS & -0 & -0.2 \\
\hline P5-Wadi & & 15 & $7.5 Y R 8 / 4$ & -- & $\bar{A}, \mathrm{~S}$ & 0 & 0.2 & 520 & 829 & 163 & 8 & 372 & 176 & 146 & 76 & 59 & LCOS & 0.06 & -0.10 \\
\hline Abu-Rowis & 35 & 10 & $7.5 \mathrm{YR} 8 / 4$ & -- & -- & 0 & 0.5 & 355 & 813 & 118 & $\begin{array}{l}6 \\
69\end{array}$ & 289 & 198 & 136 & 109 & 81 & LCOS & -- & -0 \\
\hline P6-Wadi & & $40-55$ & $7.5 \mathrm{YR} 8 / 3$ & SL & $\mathrm{A}, \mathrm{W}$ & 0 & 11.2 & 475 & 717 & 201 & 82 & 52 & 95 & 129 & 206 & 235 & FSL & 0.73 & -0.04 \\
\hline P6-Wadi & 185 & $25-45$ & $7.5 Y R 8 / 4$ & F3M & $\mathrm{A}, \mathrm{W}$ & 0 & 13.8 & 80 & 788 & 113 & 99 & 95 & 138 & 145 & 214 & 196 & LS & 0.66 & -0.40 \\
\hline Al-Ghaib & 185 & $30-60$ & $7.5 \mathrm{YR} 8 / 3$ & SL & $\mathrm{A}, \mathrm{S}$ & 0 & 12.2 & 535 & 692 & 89 & 219 & 114 & 107 & 125 & 248 & 98 & SL & -0.64 & 0.07 \\
\hline & & $60-80$ & $7.5 Y R 8 / 4$ & F3M & -- & 0 & 13.4 & 55 & 706 & 221 & 73 & 129 & 145 & 59 & 162 & 211 & LCOS & -- & -- \\
\hline & & $35-45$ & 7.5 YR6/8 & FDC; F3M & $\bar{A}, \mathrm{~S}$ & 0 & 10.5 & 35 & 666 & 245 & 89 & 41 & 89 & 214 & 124 & 198 & SL & 0.36 & 0.83 \\
\hline P7-Wadi & & $30-40$ & 7.5 YR $7 / 8$ & FDC; F3M & $\begin{array}{l}\mathrm{A}, \mathrm{S} \\
\mathrm{A}, \mathrm{S}\end{array}$ & 0 & 24.7 & 50 & 785 & 125 & $\begin{array}{l}89 \\
90\end{array}$ & $\begin{array}{l}41 \\
64\end{array}$ & $\begin{array}{l}89 \\
68\end{array}$ & 207 & $\begin{array}{l}194 \\
198\end{array}$ & $\begin{array}{l}190 \\
248\end{array}$ & SL & 0.95 & $\begin{array}{l}0.03 \\
0.71\end{array}$ \\
\hline Al-Ghaib & 175 & $15-20$ & 7.5YR8/6 & CAM; SL & $\mathrm{A}, \mathrm{S}$ & 0 & 13.5 & 145 & 862 & 95 & 43 & 145 & 228 & 196 & 137 & 156 & LS & -0.34 & $\begin{array}{l}0.44 \\
-0.44\end{array}$ \\
\hline (Dam 3) & & $40-45$ & $7.5 Y R 8 / 4$ & FDC & $\mathrm{A}, \mathrm{S}$ & 0 & 10.2 & 80 & 778 & 165 & 57 & 135 & 125 & 235 & 118 & 165 & LCOS & -0.62 & -0.44 \\
\hline & & $35-45$ & 7.5 YR6/8 & CAM; SL & -- & 0 & 11.3 & 135 & 663 & 125 & 212 & 89 & 58 & 103 & 78 & 335 & FSL & -- &.--14 \\
\hline P8-Wadi & & 10 & 7.5 YR $8 / 6$ & -- & $\mathrm{A}, \mathrm{S}$ & 0.3 & 1.1 & 430 & 920 & 53 & 27 & 305 & 206 & 351 & 33 & 25 & COS & -0.43 & -0.49 \\
\hline Mareikh & 30 & 20 & 7.5YR $8 / 4$ & -- & -- & 0.2 & 0.9 & 375 & 855 & 91 & 54 & 239 & 215 & 311 & 56 & 34 & COS &.-- &.-- \\
\hline & & $20-25$ & $7.5 \mathrm{YR} 7 / 2$ & -- & $\mathrm{A}, \mathrm{W}$ & 0.3 & 0 & 125 & 853 & 125 & 22 & 228 & 165 & 208 & 194 & 58 & LCOS & -0.35 & -0.55 \\
\hline P9-Wadi & 65 & $20-30$ & 7.5 YR7/3 & - & $\mathrm{A}, \mathrm{W}$ & 0.3 & 0 & 60 & 721 & 135 & 144 & 103 & 125 & 215 & 189 & $\begin{array}{l}30 \\
89\end{array}$ & LS & 0.23 & 1.14 \\
\hline Nasab & & $10-25$ & 7.5 YR7/2 & -- & -- & 0.1 & 0 & 40 & 847 & 133 & 20 & 209 & 199 & 247 & 106 & 86 & LCOS & -- & -- \\
\hline & & 20 & 7.5 YR7/6 & LN & $\bar{D}, \mathrm{~S}$ & 0.5 & 0.9 & 110 & 789 & 172 & 39 & 108 & 214 & 206 & 182 & 79 & LCOS & -0.37 & -0.43 \\
\hline P10-Wadi & 70 & 30 & $7.5 \mathrm{YR} 7 / 8$ & -- & $\mathrm{D}, \mathrm{S}$ & 0.3 & 1.1 & 105 & 679 & 276 & 45 & 134 & 156 & 175 & 146 & 68 & COSL & 0.37 & 0.35 \\
\hline & & 20 & $7.5 Y R 7 / 6$ & -- & -- & 0.2 & 1.5 & 90 & 741 & 232 & 27 & 105 & 240 & 191 & $\begin{array}{l}140 \\
153\end{array}$ & $\begin{array}{l}00 \\
52\end{array}$ & LCOS & -.01 & -- \\
\hline & & $10-15$ & 7.5 YR7/6 & FDG & $\mathrm{C}, \mathrm{W}$ & 3.2 & 1.6 & 30 & 710 & 195 & 95 & 38 & 93 & 334 & 147 & 98 & SL & -0.50 & -0.29 \\
\hline P11-Wadi & & $20-30$ & 7.5 YR6/6 & GYM & C.W & 8.4 & 1.4 & 50 & 634 & 260 & 106 & 101 & 85 & 167 & 105 & 176 & SL & 0.92 & $\begin{array}{l}-0.29 \\
0.54\end{array}$ \\
\hline Zoghra & 140 & 40 & 7.5 YR6/8 & SL & A,S & $\begin{array}{l}0.4 \\
2.6\end{array}$ & $\begin{array}{l}1.4 \\
1.8\end{array}$ & 875 & 727 & 231 & 42 & 210 & $\begin{array}{l}03 \\
98\end{array}$ & $\begin{array}{l}157 \\
157\end{array}$ & 176 & 86 & COSL & 0.87 & $\begin{array}{l}.0 .02 \\
-0.02\end{array}$ \\
\hline bottom & & $20-25$ & 7.5 YR7/6 & FDG & A,S & 4.3 & 1.3 & 30 & 722 & 113 & 165 & 105 & 65 & 289 & 201 & 62 & SL & 0.06 & -0.05 \\
\hline & & $35-45$ & $7.5 Y R 8 / 6$ & FDG & -- & 3.9 & 1.5 & 10 & 712 & 105 & 183 & 93 & 54 & 308 & 198 & 59 & SL & -- & -0 \\
\hline & & 15 & $7.5 \mathrm{YR} 8 / 2$ & & $\bar{A}, \mathrm{~S}$ & 0.3 & 0 & 365 & 864 & 109 & 27 & 336 & 147 & 287 & 35 & 59 & $\mathrm{COS}$ & -0.16 & -0.21 \\
\hline P12-Wadi & 85 & $40-50$ & $7.5 \mathrm{YR} 8 / 2$ & SL & A,W & 0.4 & 0 & 570 & 833 & 125 & 42 & 269 & 205 & 225 & 69 & 65 & LCOS & -0.78 & $\begin{array}{l}-0.21 \\
-0.62\end{array}$ \\
\hline Maaian & 85 & $20-30$ & $7.5 Y R 7 / 2$ & SL & A, & 0.3 & 0 & 15 & $\begin{array}{l}035 \\
652\end{array}$ & 229 & 119 & 95 & 79 & 109 & 131 & 238 & FSL & -0.10 & -0.02 \\
\hline P13-Wadi & & 20 & $7.5 \mathrm{YR} 7 / 2$ & -- & $\mathrm{C}, \mathrm{S}$ & 0 & 0 & 95 & 699 & 210 & 91 & 135 & 98 & 359 & 95 & 12 & SL & 0.90 & 1.62 \\
\hline Shuki & 60 & 40 & 7.5YR7/1 & SL & -- & 0 & 0 & 385 & 859 & 91 & 50 & 217 & 159 & 401 & 35 & 47 & LCOS & -- &.-- \\
\hline P14-Wadi & & $35-45$ & $7.5 \mathrm{YR} 8 / 3$ & -- & $\mathrm{C}, \mathrm{W}$ & 0.2 & 0 & 370 & 730 & 210 & 60 & $\frac{11}{79}$ & 145 & 214 & 117 & 175 & SL & 0.92 & 0.55 \\
\hline Abu-hashab & 95 & 35 & $7.5 Y R 7 / 3$ & -- & $\mathrm{C}, \mathrm{W}$ & 0.3 & 0 & 430 & 807 & 148 & 45 & 198 & 210 & 159 & 135 & 105 & LCOS & 0.22 & 0.28 \\
\hline bottom & & $15-25$ & $7.5 \mathrm{YR} 7 / 2$ & SL & -- & 0.2 & 0 & 275 & 843 & 121 & 36 & 217 & 197 & 235 & 95 & 99 & LS &.-- & -- \\
\hline P15-Wadi & & $30-35$ & $7.5 \mathrm{YR} 6 / 1$ & SL & $\mathrm{D}, \mathrm{W}$ & 0.1 & 0 & 535 & 779 & 172 & 49 & 154 & 139 & 164 & 197 & 125 & LCOS & -0.25 & 0.02 \\
\hline Um-Ism & 70 & $15-20$ & $7.5 Y R 7 / 1$ & -- & D.W & 0.4 & 0 & 395 & 782 & 159 & 59 & 117 & 105 & 176 & 189 & 195 & LS & 0.28 & 0.027 \\
\hline bottom & & 20 & 7.5YR6/1 & $\overline{\mathrm{SL}}$ & -- & $\begin{array}{l}0.4 \\
0.2\end{array}$ & 0 & $\begin{array}{l}395 \\
480\end{array}$ & 820 & $\begin{array}{l}159 \\
135\end{array}$ & $\begin{array}{l}39 \\
45\end{array}$ & 175 & $\begin{array}{l}105 \\
142\end{array}$ & 131 & $\begin{array}{l}189 \\
201\end{array}$ & $\begin{array}{l}195 \\
171\end{array}$ & $\begin{array}{l}\mathrm{LS} \\
\text { LCOS }\end{array}$ & 0.28 & 0.27 \\
\hline & & 25 & $7.5 \mathrm{YR} 8 / 2$ & CAM & $\mathrm{A}, \mathrm{W}$ & 1.3 & 24.6 & 35 & 685 & 158 & 157 & 59 & 89 & 135 & 137 & 265 & FSL & 0.32 & -0.04 \\
\hline P16-Wadi & & $15-65$ & $7.5 Y R 8 / 3$ & CAM & C.B & 0.9 & 16.3 & 40 & 677 & $98^{\circ}-1$ & 225 & 65 & 118 & 148 & 109 & 237 & SCL & 0.99 & 0.37 \\
\hline Dahab's & 210 & $15-85$ & $7.5 Y R 7 / 3$ & CAC & $\mathrm{C}, \mathrm{B}$ & 0.6 & 10.5 & 145 & 742 & 136 & 122 & 205 & 124 & 217 & 89 & 107 & COSL & -0.65 & -0.07 \\
\hline $\begin{array}{l}\text { delta } \\
\text { de }\end{array}$ & & $20-65$ & 7.5YR $8 / 4$ & FDC & $\mathrm{A}, \mathrm{S}$ & 0.7 & 13.8 & 45 & 727 & 192 & 81 & 35 & 109 & 194 & 104 & 285 & SL & 0.53 & -0.01 \\
\hline & & $45-85$ & $7.5 Y R 8 / 3$ & FDC & -- & 0.8 & 9.7 & 25 & 726 & 177 & 97 & 98 & 151 & 149 & 131 & 197 & $\mathrm{SL}$ & -- & -- \\
\hline
\end{tabular}

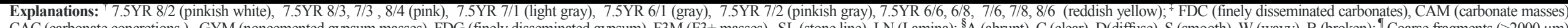

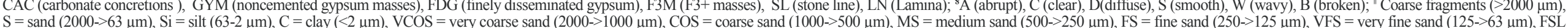
$\mathrm{S}=$ sand $(2000->63 \mu \mathrm{m}), \mathrm{Si}=$ silt $(63-2 \mu \mathrm{m}), \mathrm{C}=$ clay $(<2 \mu \mathrm{m}), \mathrm{VCOS}=\mathrm{very}$ coarse sand $(2000->1000 \mu \mathrm{m}), \mathrm{COS}=$ coarse sand $(1000->500 \mu \mathrm{m}), \mathrm{MS}=$ medium sand $(500->250 \mu \mathrm{m}), \mathrm{FS}=$ fine sand $(250->125 \mu \mathrm{m}), \mathrm{VFS}=\mathrm{very}$ fine sand $(12)$ (fine sandy loam), LCOS (loamy coarse sand), COSL (coarse sandy loam), SL (sandy loam), SCL (sandy clay loam); $\mathrm{UV} 1$ (uniformity value index of Cremeens and Mokma, 1986), UV2 (uniformity value index of Kowalska et al., 2016) 

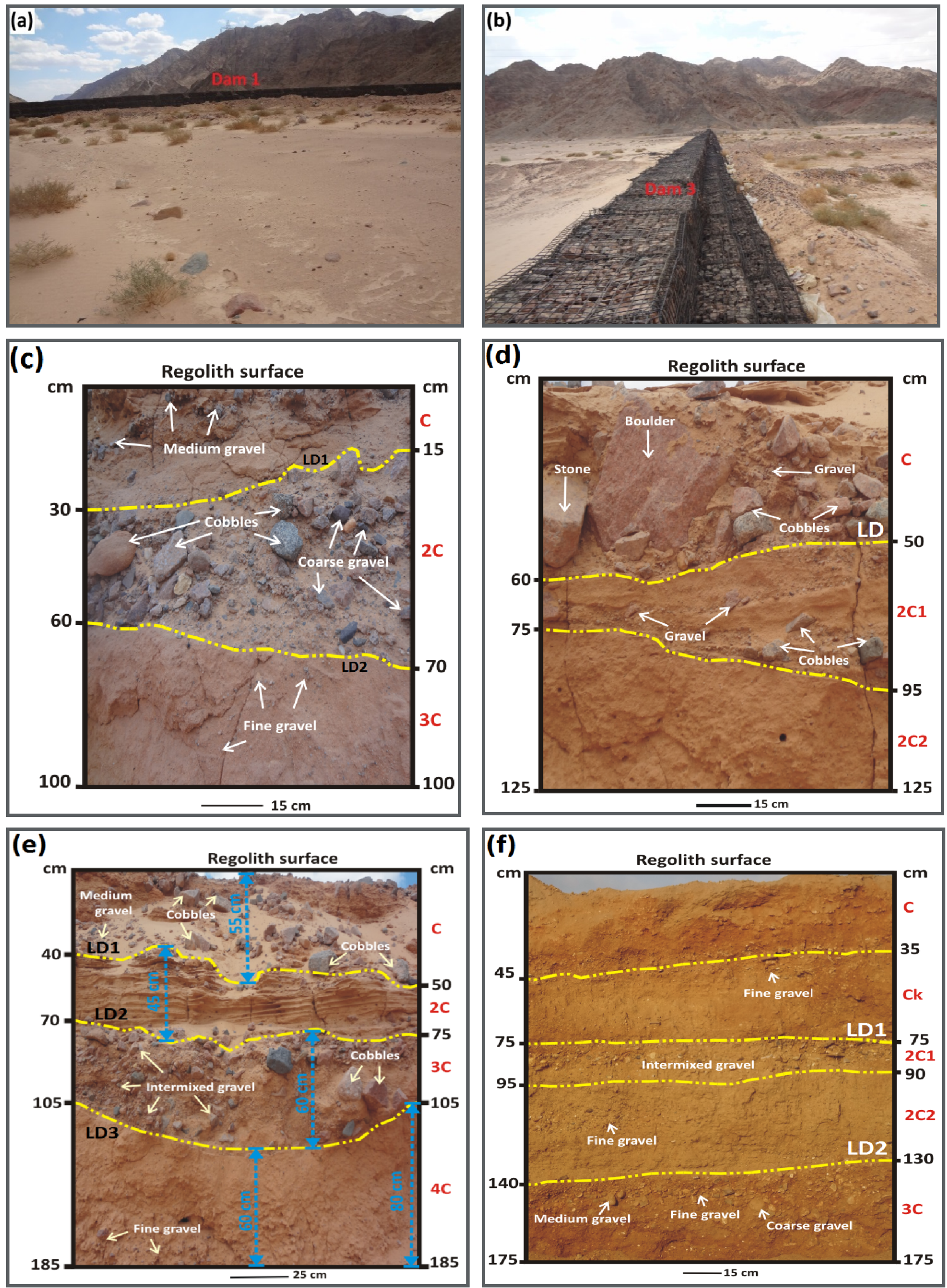

Fig. (4): Examples of landscapes and sediment pedons of Wadi Al-Ghaib and its subtributaries. (a) Dam-controlled watershed of Wadi Al-Gibby; (b) Dam-controlled watershed of Wadi Al-Ghaib; (c) P1-Wadi Abu-Gardat; (d) P2- Wadi Al-Gibby behind the check dam 1; (e,f) P6 and P7 of Wadi Al-Ghaib behind the check dams 2 and 3, respectively. Yellow dashed lines represent the boundaries between the pedon layers/horizons, some of which represent the lithologic discontinuities 

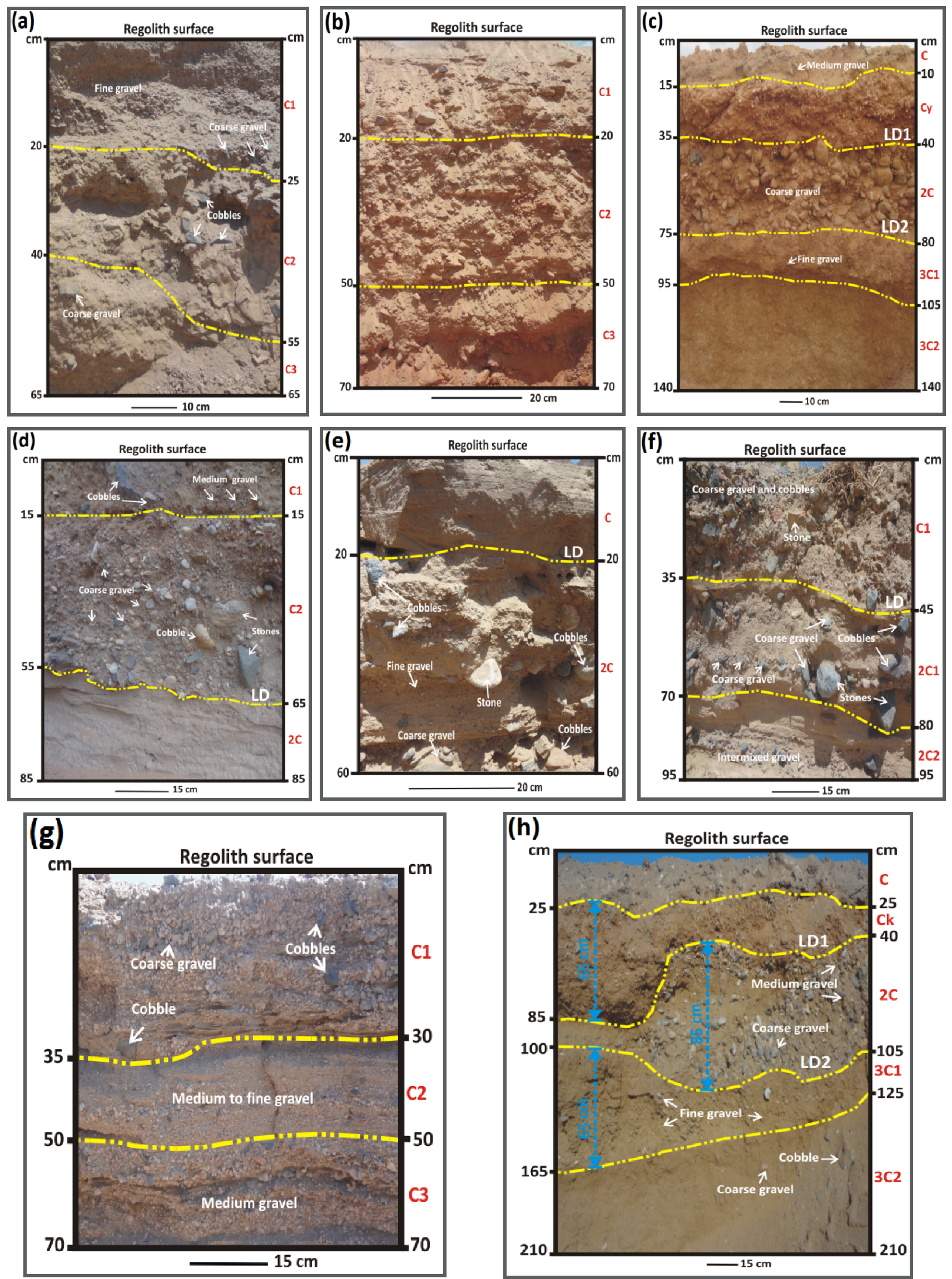

Fig. (5): Analysed pedons of Wadi Zoghra and its subtributaries (a, b, c), Wadi Abu-Khashab and its subtributaries (d, e, f), Wadi Um-Ism (g), and delta of Wadi Dahab (h) to illustrate the distribution of lithologic discontinuities. (a) P9-Wadi Nasab; (b) P10-Wadi Al-Hamam; (c) P11-Wadi Zoghra downstream; (d) P12-Wadi Maaian; (e) P13-Wadi Shuki; (f) P14-Wadi Abu-Khashab; (g) P15-Wadi Um-Ism; (h) P16-Delta Wadi Dahab. Yellow dashed lines represent the boundaries between the pedon layers/horizons, some of which represent the lithologic discontinuities 
In general, soil textures vary from coarse sand in soils from upslopes through loamy sand in soils developed at midslopes to sandy clay loam in soils deposited at downslope of Wadi Dahab's delta. In all studied pedons, the sand was a dominant fraction. Total sand content in the subtributaries was higher compared to downslope of the main tributaries and ranged from $637 \mathrm{~g} \mathrm{~kg}^{-1}$ in Wadi Al-Gibby to $920 \mathrm{~g} \mathrm{~kg}^{-1}$ in Wadi Mareikh; and from $634 \mathrm{~g} \mathrm{~kg}^{-1}$ in Wadi Zoghra to $862 \mathrm{~g}$ $\mathrm{kg}^{-1}$ in Wadi Al-Ghaib, respectively. While in Wadi Dahab's delta, total sand narrowly ranged from $677 \mathrm{~g}$ $\mathrm{kg}^{-1} 742 \mathrm{~g} \mathrm{~kg}^{-1}$. The fraction of silt in all studied pedons oscillated from $39 \mathrm{~g} \mathrm{~kg}^{-1}$ in Wadi Hadaba (Wadi AlGhaib's subtributary) to $276 \mathrm{~g} \mathrm{~kg}^{-1}$ in Wadi Al-Hamam (Wadi Zoghra's subtributary). Clay content in the ten subtributaries (8-148 $\mathrm{g} \mathrm{kg}^{-1}$ ) was lower than in the four main tributaries (36-219 $\mathrm{g} \mathrm{kg}^{-1}$ ) and Wadi Dahab's delta (81-225 $\mathrm{g} \mathrm{kg}^{-1}$ ) (Table 2). The highest values of clay content were observed in the subsurface layer of P16 (225 $\left.\mathrm{g} \mathrm{kg}^{-1}\right)$, the third layer of P6 (219 $\left.\mathrm{g} \mathrm{kg}^{-1}\right)$, the deepest layer of P7 (212 $\left.\mathrm{g} \mathrm{kg}^{-1}\right)$, and the deepest layer of P11 (183 $\left.\mathrm{g} \mathrm{kg}^{-1}\right)$. In contrast, pedons located at upslope in the subtributaries presents the highest sand content which may be attributed to the coarse sedimentary nature of the material from which upper positions sediments of Wadi Dahab were formed. Wadi Um-Ism consisted of Quaternary alluvial loamy coarse sand to loamy sand in a moderately shallow deep regolith (70 $\mathrm{cm}$ ) (Fig. 5g). Similarly, the soil of Wadi Abu-Khashab downstream was mapped as a moderately deep $(95 \mathrm{~cm})$, loamy coarse sand to sandy loam, and mantled by coarse sediments (275-370 $\left.\mathrm{g} \mathrm{kg}^{-1}\right)$ (Fig. 5d,e,f).

Gypsum and lime contents are related to the kind of parent material and slope position. Gypsum content was observed in Wadi Zoghra and its subtributaries while it was absent in Wadi Al-Ghiab and its tributaries. P11-Wadi Zoghra has the highest gypsum contents ranging from $2.6 \%$ in the $2 \mathrm{C}$ layer to $8.4 \%$ in $\mathrm{Cy}$ horizon. In comparison, $\mathrm{CaCO}_{3}$ content was higher in the lower positions at Wadi Al-Ghaib and Wadi Daha's delta ranging from $9.7 \%$ (moderately calcareous) to $24.7 \%$ (strongly calcareous) (FAO, 2006). While the slightly calcareous sediment $(0.9-1.8 \%)$ was occurred only within the pedons of Zoghra and its subtributaries, except Wadi Nasab which was noncalcareous. Moreover, Wadi Abu-Khashab including its subtributaries and Um-Ism has $0.0 \% \mathrm{CaCO}_{3}$ content. Pedons from Wadi Al-Ghaib and its subtributaries, except P5-Wadi Abu-Rowis, are highly affected by the calcareous nature compared with other tributaries. The laboratory data was found to be consistent with the morphological description, showing parallels to the $\mathrm{CaCO}_{3}$ content. The concentrations of secondary lime, gypsum, and iron masses were the most pedogenic characters in downslope pedons such as P6, P7, P11, and P16 (Table 2). Accumulation of secondary carbonate (P7 and P16) and gypsum (P11) qualifies as calcic and gypsic horizons, respectively.

Genetic horizon boundaries provide information on the dominant soil-forming processes that have formed the soil (FAO, 2006) while layer boundaries provide evidence for the past geogenic processes. Evidence cited for LD sharp and wavy boundaries, strong textural contrasts, stone lines. Boundaries between $\mathrm{C}$ layers in studied pedons are varied in both distinctiveness and topography. Abrupt smooth boundaries were the dominant within the most investigated pedons (Figs. 4, 5 and Table 2). The occurrence of smooth to broken and abrupt to diffuse boundaries in studied pedons is often cited as field evidence for a LD (Schaetzl and Anderson, 2005; Soil Survey Staff, 2014a). Diffuse smooth C1-C2 and $\mathrm{C} 2-\mathrm{C} 3$ boundaries occurred only in P10-Wadi AlHamam (Zoghra's subtributay) that has the same geological parent material. In P16-Wadi Dahab's delta, the soil exhibited clear broken $\mathrm{Ck}-2 \mathrm{C}$ and $2 \mathrm{C}-3 \mathrm{C} 1$ boundaries indicating two unlike parent material with different modes of deposition occurring on older, more stable surfaces, however the wavy boundary was found between $\mathrm{C}-\mathrm{Ck}$ horizons and smooth boundary was between 3C1-3C2 layers indicating same materials (Fig. $5 \mathrm{~h}$ and Table 2). The boundary investigations advocated that the layer/horizon boundaries in studied pedons failed to detect the real LDs in soils. This may be attributed to the boundary between two layers are identified based on color, texture, structure, hardness, or other features which largely influenced by the pedogenic process. Consequently, horizon/layer boundary was a very poor morphologic indicator for detecting LDs in studied soils.

Based on the field observations, the coarse fragments tend to be distinctive to LD. Stone lines and lamina (geogenically deposited strata or layers of alternating texture) were the most geologic features recorded in most studied pedons (Table 2). The visual estimation of rock fragments showed abrupt changes vertically within the pedon layers which were not resulting from pedogenic processes. Accordingly, LDs are often indicated by an erratic distribution of rock fragments within the investigated pedons. Most studied pedons (e.g., P1, P2, P3, P4, P5, P6, P8, P9, P11, P12, $\mathrm{P} 13, \mathrm{P} 14$, and $\mathrm{P} 15)$ of the toposequences have coarse fragments content exceeding $150 \mathrm{~g} \mathrm{~kg}^{-1}$. In comparison, pedons in the lower positions (P7, P10, and P16) have less than $150 \mathrm{~g} \mathrm{~kg}^{-1}$ coarse fragments content (Table 2). The stone line of microcrystalline quartz (chert) was abundant within P11-Wadi Zoghra (40 cm thickness) indicating two LDs at $35 \mathrm{~cm}$ and $75 \mathrm{~cm}$ (Fig. 5c). It is a natural concentration of rock fragments (chert) caused by water erosion or transport erosional lag (Schoeneberger et al., 2012). The material (Cy) above the stone line is most likely transported, and the material below may be of different origin (Soil Survey Staff, 2014a). This observation represents different mechanisms of transport (colluvial, aeolian and alluvial) with different transport distances (Table 1). Morphological field description of rock fragments abundance indicated discontinuities stared at: 15-30 and 60-70 cm for P1 (Fig. 4c); 50-60 cm for P2 (Fig. 4d); 40-50 cm, 70-75 cm, $105 \mathrm{~cm}$ for P6 (Fig. 4e). Colluvial pedons at Wadi Al-Ghaib's subtributaries present 1-2 LDs (Fig. 4c,d). Two LDs as different alluvium sources were identified in P7 (at depths of $75 \mathrm{~cm}$ and 130-140 $\mathrm{cm}$ ) (Fig. 4f). By contrast, LDs were absent in other pedons of Wadi Al-Ghaib's subtributaries (P3, P4, and P5). 
The occurrence of LDs was proven using the uniformity indices (UV1, UV2) (Table 2). The difference in sand and silt separates of UV1 on a carbonate-free, clay-free basis was consistent with the vertical distribution of rock fragments within the pedon (Table 2). Accordingly, an abrupt change in PSD, which is not resulting from pedogenesis, was observed in most studied pedons that have high values of UV1. Hence, the analysed pedons (P1, P2, P6, P7, P11, P12, P13, P14 and P16) were considered LDs. The observed differences in UV1 between the different layers were greater than 0.60 . By contrast, the UV2 values were less than 0.60 (Table 2) in most of these pedons indicated no differences in the pedon materials which are not consistent with the morphological indicators (e.g., inverse distribution of rock fragments and stone line). The lower values of UV2 observed in most studied pedons indicate the limitation of this method which failed to estimate the uniformity of parent material.

\section{Geochemical element characteristics}

Element composition of the pedons across Wadi Dahab's tributaries are given in Table (3). In general, oxides of $\mathrm{Si}, \mathrm{Al}$, and $\mathrm{Fe}$ made up the greatest percentage of the major element oxides in the sediments from all wadis poured in Wadi Dahab. The concentrations of oxides in soils are varied but $\mathrm{SiO}_{2}, \mathrm{Al}_{2} \mathrm{O}_{3}$ and $\mathrm{Fe}_{2} \mathrm{O}_{3}$ had the highest concentrations among all the oxides. Accordingly, $\mathrm{Al}_{2} \mathrm{O}_{3}, \mathrm{SiO}_{2}$, and $\mathrm{Fe}_{2} \mathrm{O}_{3}$ are the three major elements in studied sediments representing more than $65 \%$ of the total components. Findings of the geochemical analysis showed that the sediments of Wadi Al-Ghaib composed of 55.12-82.65\% $\mathrm{SiO}_{2}$, 2.627.08\% $\mathrm{Al}_{2} \mathrm{O}_{3}, 1.89-38.32 \% \quad \mathrm{Fe}_{2} \mathrm{O}_{3}, 0.09-3.30 \% \mathrm{MgO}$, $1.19-6.08 \% \mathrm{CaO}, 1.75-4.10 \% \mathrm{Na}_{2} \mathrm{O}, 0.09-5.40 \% \mathrm{~K}_{2} \mathrm{O}$, with low concentrations of $\mathrm{TiO}_{2}, \mathrm{P}_{2} \mathrm{O}_{5}, \mathrm{MnO}$, and $\mathrm{Cr}_{2} \mathrm{O}_{3}$ which all are less than $1 \%$. The higher values of $\mathrm{Fe}_{2} \mathrm{O}_{3}$ were registered in Wadi Al-Gibby (26.32-38.32\%) and Wadi Abu-Gardat (23.56-31.25\%) while the lower values were found in other Wadi Al-Ghaib's subtributaries. The most abundant geochemical elements in Wadi Zoghra sediments were $\mathrm{SiO}_{2}$ (57.65-73.63\%), $\mathrm{Al}_{2} \mathrm{O}_{3}$ (6.94-14.95\%), $\mathrm{Fe}_{2} \mathrm{O}_{3}(0.47-9.65 \%), \mathrm{CaO}(0.36-$ $5.52 \%)$, and $\mathrm{Na}_{2} \mathrm{O}(1.98-4.99 \%)$. In contrast, the sediments of Wadi Abu-Khashab were dominated by $\mathrm{SiO}_{2}$ (58.25-66.25\%), $\mathrm{Na}_{2} \mathrm{O}$ (4.35-6.59\%), $\mathrm{Al}_{2} \mathrm{O}_{3}$ (4.25$6.01 \%), \mathrm{CaO}(4.25-7.12 \%)$, and $\mathrm{MgO}(2.15-7.28 \%)$ with low concentrations of $\mathrm{Fe}_{2} \mathrm{O}_{3}(0.06-1.55 \%), \mathrm{K}_{2} \mathrm{O}$ (1.03$2.51 \%)$, and $\mathrm{TiO}_{2}(0.08-1.61 \%)$ while concentrations of other elements are less than $1 \%$ for each. In the sediments of Wadi Um-Ism, the analysed oxides were ordered as follows: $\mathrm{SiO}_{2}$ (58.32-60.26\%), $\mathrm{CaO}$ (6.12-6.69\%), $\mathrm{Na}_{2} \mathrm{O}$ (3.95-4.25\%), $\mathrm{MgO}$ (3.47-3.65\%), $\mathrm{Al}_{2} \mathrm{O}_{3}$ (2.95-3.15\%), $\mathrm{Fe}_{2} \mathrm{O}_{3}(2.45-3.12 \%)$, and $\mathrm{K}_{2} \mathrm{O}(1.25-1.79 \%)$ with less concentrations of other oxides $(<1 \%)$.

The weatherd sediments of Wadi Dahab's delta showed decrease in $\mathrm{SiO}_{2}(48.25-50.35 \%), \mathrm{Na}_{2} \mathrm{O}$ (1.68$2.61 \%)$, and $\mathrm{K}_{2} \mathrm{O} \quad(1.33-2.29 \%)$ concentrations, compared to Dahab's tributaries, with increasing degree of weathering and distance from the source rock, which may be attributed to the direct loss of $\mathrm{SiO}_{2}, \mathrm{Na}_{2} \mathrm{O}$, and $\mathrm{K}_{2} \mathrm{O}$ during the decomposition of feldspars. By contrast, $\mathrm{CaO}$ concentration (6.89-9.05\%) showed a different trend where it increased against the usual by decreasing the slope and increasing the weathering which may be attributed to the presence of secondary carbonates (9.7$24.6 \% \mathrm{CaCO}_{3}$ ) (Tables 2 and 3). The same trend also occurred in the calcareous sediments of Wadi Al-Ghaib ( $\mathrm{P} 2, \mathrm{P} 3, \mathrm{P} 6$, and $\mathrm{P} 7)$, where the higher values of $\mathrm{CaO}$ (2.9-6.08\%) were highly correlated to $\mathrm{CaCO}_{3}$ content (9.4-27.7\%) (Tables 2 and 3). While other oxides; e.g., $\mathrm{Al}_{2} \mathrm{O}_{3}(13.05-17.05 \%), \mathrm{Fe}_{2} \mathrm{O}_{3}(6.15-9.12 \%)$, and $\mathrm{TiO}_{2}$ (1.15-3.65\%) increased with increasing the distance from the upslope to downslope $(239 \mathrm{~km})$, which may be attributed to formation of clay minerals and change $\mathrm{FeO}$ into $\mathrm{Fe}_{2} \mathrm{O}_{3}$ during weathering process (Tables 1, 2 and 3). This finding indicates that the oxidation is an important weathering process for iron-bearing minerals such as biotite commonly found in Wadi Dahab sediments. Concentrations of $\mathrm{SiO}_{2}$ were significantly higher in soils from subtributaries compared to those of tributaries and Wadi Dahab's delta.

The siliceous nature of the soils is similar to those reported by Young et al. (2010) in geophagic soils from Zanzibari, but the content of ferric oxides in sediments from Wadi Dahab Basin was higher. Higher concentration of $\mathrm{SiO}_{2}$ in the soils is explained by the dominance of quartz in the samples whereas the presence of Fe-containing minerals including hematite and goethite would explain the observed ferric oxide concentrations. Low concentrations of the oxides of cations $\mathrm{Mg}, \mathrm{K}$, and $\mathrm{Na}$ in soils of the Wadi Dahab's delta brings in contrast to $\mathrm{Ca}$ to question the ability of these soils to serve as nutrient supplements for these elements.

The concentrations of specific oxides are used as an indication of the degree of soil weathering. Weathering indices are commonly used in comparing the extent of chemical alteration in different materials (Darmody et al., 2005). The indices are based on the principle that the ratio between concentrations of mobile (e.g., $\mathrm{SiO}_{2}, \mathrm{CaO}, \mathrm{MgO}$, and $\mathrm{Na}_{2} \mathrm{O}$ ) and immobile elements (e.g., $\mathrm{Al}_{2} \mathrm{O}_{3}, \mathrm{Fe}_{2} \mathrm{O}_{3}$, and $\mathrm{TiO}_{2}$ ) should decrease over time as leaching progresses. Table (3) presents the weathering indices calculated for all pedons and their horizons/layers. The $\mathrm{CaO}$ concentration used in CIA, and CIW indices, is varied across the Dahab drainage Basin. It is directly related to the source rock and $\mathrm{CaCO}_{3}$ content in the weathered sediments (Tables 2 and 3). In accordance with these findings, the pedon sequences of Wadi Abu-Khashab and Um-Ism are completely free of carbonates and the sediments from Wadi Zoghra and its subtributaries are slightly calcareous. In Wadi Al-Ghaib and its subtributaries, the CIA values ranged from 23.7 to $48.1 \%$, and the CIW values ranged from $28.3 \%$ in $\mathrm{P} 4$ to $51.4 \%$ in $\mathrm{P} 7$. These values indicated that the Wadi Al-Ghaib sediments lacked to the chemical weathering. By contrast, the CPA values in Wadi Al-Ghaib and its subtributaries varied from $46.0-77.5 \%$. The highest values were registered in P7, indicating the occurrence of the chemical weathering. Howover, in the carbonate-free sediments as in Wadi Abu-Khashab and Um-Ism, the values CPA, CIA, and CIW indices were below 55\% indicating the abundance of the physical weathering. 
Furthermore, the three indices recorded values above the 55\% within P11-Wadi Zoghra: 82.3-87.7\% CPA, 61.0-68.8\% CIA, and 76.8-82.6\% CIW, indicating the occurrence of the chemical weathering. According to the CPA index, the sediments of Dahab Basin at its downslope appear more weathered than its upslope.

\section{Light minerals}

Light minerals are composed mainly of quartz and feldspars (Table 4). Quartz in soil occurs as an inherited primary mineral from soil parent materials. Because of its resistance to weathering, compared with feldspars, the percentage of quartz increases in soil over time as less resistant minerals breakdown. Quartz is one of the most significant variables in the soil of the Wadi Dahab Basin. It varies from 83.65 to $99.22 \%$ as the most abundant mineral in the soil C-horizon. The high and low quartz concentration was related directly to soil parent materials (Galovic' and Peh, 2016). In general, soil within the Wadi Al-Ghaib catena is quartz-rich and formed on Late Cretaceous to Holocene marine, predominantly clastic, sedimentary rocks, and aeolian deposits. The quartz-rich soil in this region is mostly formed on sandstone colluvium or from aeolian or alluvial deposits. Soil developed on alluvial sand in the downstream of Wadi Dahab also has high quartz concentrations.

The interplay of moisture and temperature is a major factor in determining soil characteristics (Woodruff et al., 2015), and the flooding effects are strongly imprinted on the distribution of many elements and minerals across Wadi Dahab Basin. One of the most fundamental changes in soil composition across Wadi Dahab Basin is the weathering of feldspar in soil along the gradient of increased precipitation from the Rocky Mountains to the east coast. Feldspar minerals are very reactive in the soil environment, typically breaking downslope by hydrolysis and leaching to form the clay mineral kaolinite while releasing $\mathrm{Ca}, \mathrm{Na}$, or $\mathrm{K}$ cations into solution. Feldspar, prevalent in the soil, sourced from metamorphic and igneous rocks in Wadi Zoghra, gives way to the soil in Wadi Dahab Basin formed from similar parent materials from which the original feldspar has been largely obliterated by weathering (Yang et al., 2018). Downstream of Wadi Zoghra, Wadi Al-Ghaib, and Wadi Dahab's delta are moderately weathered and most feldspar may be altered to Al-rich clay (Woodruff et al., 2015). This loss of feldspar in soil is expressed not only mineralogically by transformation of feldspar to kaolinite and then to gibbsite (Yang et al., 2018), but chemically in the leaching of nearly all major and trace elements present in the feldspar structure (Tables 3 and 4) (Woodruff et al., 2015).

\section{Heavy mineral assemblages}

It has been observed that a fair concentration and a number of heavy minerals species have been recorded from the sediments of the study area (Table 4). The heavy minerals assemblage in Wadi Dahab Basin varied with lithology structure and landscape position. Heavy mineral percentages by weight increased across the slope gradient (1.25 - 12.36\%), with a marked transition from the upper to the lower slopes. Heavy mineral concentrations in Wadi Al-Ghaib and its subtributaries vary from $1.25 \%$ in wadis Hadaba and Um-Markha to $7.04 \%$ in P7 at dam-controlled Wadi Al-Ghaib watershed. A similar trend of heavy minerals percentage occurred in other main tributaries: Wadi Zoghra and its subtributaries (2.14 - 10.67\%), Wadi Abu-Khashab and its subtributaries $(2.45-4.23 \%)$, Wadi Um-Ism (1.98 $2.36 \%$ ), which increased with decreasing elevation. The highest concentration of heavy minerals (8.36 - 12.36\%) was detected in the Wadi Dahab's delta. The increasing trend may be ascribed to the deposition of stability heavy minerals from upper tributaries and surrounding lithology. The distribution of heavy mineral characteristics in the sediments of Wadi Dahab Basin is related to the type of lithology rocks. The main heavy minerals, identified in the Wadi Dahab Basin sediments from the upper tributaries to the delta, were tourmaline, rutile, zircon, monazite, biotite, staurolite, garnet, zoisite, kyanite, epidote, augite, hornblende, olivine, and opaques. This heavy minerals assemblage varied from ultrastable to very unstable minerals (Table 4). Olivine, hornblende, and augite show a descending trend from the upstream to the downstream, whereas epidote, zircon, rutile, and tourmaline show an increasing trend at the downslope.

In Wadi Al-Ghaib and its subtributaries, opaques (35.9 - 55.5\%), hornblende (3.78 - 25.65\%), zircon (3.25 - 17.05\%), tourmaline (3.25 - 16.97\%), biotite $(2.08-12.35 \%)$, and monazite $(1.15-10.68 \%)$ were recorded as the dominant heavy minerals, with the absence of zoisite in Wadi Hadaba, Wadi Um-Markha, and Wadi Abu-Rowis. Sediments from Wadi Zoghra and its subtributaries were dominated by opaques $(31.47$ - 48.4\%), kyanite $(1.21$ - $21.65 \%)$, biotite (2.64 $17.27 \%)$, zircon $(2.19-12.26 \%)$, garnet $(0.25-$ $11.45 \%)$, epidote $(0.05-11.24 \%)$, tourmaline $(1.35$ $13.65 \%)$, rutile (2.36-11.74), monazite $(2.89-9.31 \%)$, staurolite $(1.21-9.25 \%)$, zoisite $(1.25-7.25 \%)$, hornblende $(0.15-5.25 \%)$, and olivine $(0.34-5.08 \%)$. High concentrations of epidote, kyanite, zoisite, garnet, and staurolite were found in wadi Mareikh and Nasab compared with Al-Hamam and Wadi Zoghra bottom. The highest concentration of olivine (4.65 - 5.08\%) was recorded in P8-Wadi Mareikh subtributary of Wadi Zoghra, and the lowest concentration (0.34 - 0.69\%) was found in Wadi Zoghra bottom which may be attributed to its instability and the rapid erosion from upslope to downslope.

Furthermore, heavy minerals in Wadi AbuKhashab and its subtributaries were dominated by opaques $(33.3-49.5 \%)$, tourmaline $(3.25-8.45 \%)$, biotite $(0.3-8.25 \%)$, hornblende $(3.26-7.98 \%)$, augite $(1.32-6.11 \%)$, olivine $(0.25-6.25 \%)$, and zircon $(3.01$ - 5.07). While the sediments from Wadi Um-Ism contains 56.1 - $58.3 \%$ opaques, 10.36 - $13.65 \%$ hornblende, $5.58-7.94 \%$ augite, $5.15-6.75 \%$ biotite, and $2.63-3.25 \%$ olivine. Other important but minor heavy minerals were less than $1 \%$ with traces of epidote, kyanite, and zoisite. The heavy mineral suite in the sediments of Wadi Dahab's delta at downslope were dominated by opaques $(31.3-41.2 \%)$, zircon $(13.25$ $18.35 \%)$, tourmaline $(13.78-16.85 \%)$, biotite $(9.13-$ $13.86 \%)$, rutile (4.65-7.69\%), and garnet (3.46 - 6.34\%). 
Table (3): Elemental composition of sediment samples across Wadi Dahab's tributaries and subtributaries

\begin{tabular}{|c|c|c|c|c|c|c|c|c|c|c|c|c|c|c|c|}
\hline \multirow{2}{*}{ Pedon ID } & \multirow{2}{*}{ Layer/horizon } & \multirow{2}{*}{$\mathrm{SiO}_{2}$} & \multirow{2}{*}{$\mathrm{Al}_{2} \mathrm{O}_{3}$} & \multirow{2}{*}{$\mathrm{Fe}_{2} \mathrm{O}_{3}$} & \multirow{2}{*}{ MgO } & \multirow{2}{*}{$\mathrm{CaO}$} & \multirow{2}{*}{$\mathrm{Na}_{2} \mathrm{O}$} & \multirow{2}{*}{$\mathbf{K}_{2} \mathbf{O}$} & \multirow{2}{*}{$\mathrm{TiO}_{2}$} & \multirow{2}{*}{$\mathrm{P}_{2} \mathrm{O}_{5}$} & \multirow{2}{*}{ MnO } & \multirow{2}{*}{$\mathrm{Cr}_{2} \mathrm{O}_{3}$} & \multicolumn{3}{|c|}{ Weathering indices ${ }^{\dagger}$} \\
\hline & & & & & & & & & & & & & CPA & CIA & CIW \\
\hline \multirow{2}{*}{$\begin{array}{l}\text { P1-Wadi } \\
\text { Abu-Gardat }\end{array}$} & $\underset{2 \mathrm{C}}{\mathrm{C}}$ & $\begin{array}{l}72.58 \\
82.65\end{array}$ & $\begin{array}{l}3.35 \\
3.25\end{array}$ & $\begin{array}{l}23.56 \\
27.32\end{array}$ & $\begin{array}{l}0.25 \\
0.14\end{array}$ & $\begin{array}{l}2.25 \\
1.19\end{array}$ & $\begin{array}{l}3.94 \\
2.98\end{array}$ & $\begin{array}{l}0.15 \\
0.27\end{array}$ & $\begin{array}{l}0.69 \\
0.75\end{array}$ & $\begin{array}{l}0.35 \\
0.19\end{array}$ & $\begin{array}{l}0.08 \\
0.25\end{array}$ & $\begin{array}{l}0.001 \\
0.002\end{array}$ & $\begin{array}{l}46.0 \\
52.2\end{array}$ & $\begin{array}{l}34.6 \\
42.3\end{array}$ & $\begin{array}{l}35.1 \\
43.8\end{array}$ \\
\hline & $3 \mathrm{C}$ & 79.15 & 2.62 & 31.25 & 0.35 & 1.52 & 2.84 & 0.31 & 0.35 & 0.75 & 0.32 & 0.004 & 48.0 & 35.9 & 37.5 \\
\hline P2-Wadi & $\mathrm{C}$ & 78.65 & 6.65 & 38.32 & 0.09 & 4.95 & 2.35 & 0.61 & 0.08 & 0.94 & 0.09 & 0.004 & 73.9 & 45.7 & 47.7 \\
\hline Al-Gibby & $2 \mathrm{C} 1$ & 67.32 & 5.25 & 26.32 & 0.32 & 3.88 & 1.97 & 0.09 & 0.91 & 0.18 & 0.05 & 0.002 & 72.7 & 46.9 & 47.3 \\
\hline (Dom 1) & $2 \mathrm{C} 2$ & 63.15 & 5.13 & 29.15 & 0.29 & 3.29 & 2.12 & 0.12 & 0.42 & 0.32 & 0.03 & 0.003 & 70.8 & 48.1 & 48.7 \\
\hline P3-Wadi & $\mathrm{C} 1$ & 61.05 & 5.84 & 4.20 & 1.24 & 3.56 & 3.97 & 2.71 & 0.52 & 0.17 & 0.07 & 0.001 & 59.5 & 36.3 & 43.7 \\
\hline Hadabg & $\mathrm{C} 2$ & 63.15 & 4.83 & 3.95 & 1.35 & 3.27 & 4.10 & 2.90 & 0.55 & 0.17 & 0.08 & 0.002 & 54.1 & 32.0 & 39.6 \\
\hline Hadaba & $\mathrm{C} 3$ & 64.42 & 4.47 & 4.19 & 1.22 & 2.90 & 4.08 & 2.58 & 0.49 & 0.18 & 0.08 & 0.002 & 52.3 & 31.9 & 39.0 \\
\hline P4-Wadi & $\mathrm{C1}$ & 68.13 & $\begin{array}{l}3.15 \\
3.08\end{array}$ & 2.20 & 2.70 & $\begin{array}{l}3.80 \\
4.90\end{array}$ & 3.50 & 1.80 & 0.92 & 0.23 & 0.12 & 0.005 & 47.4 & 25.7 & 30.1 \\
\hline Um-Markha & $\mathrm{C} 2$ & 69.12 & 3.08 & 2.90 & 3.30 & 4.90 & 2.90 & 2.10 & 0.81 & 0.26 & 0.09 & 0.004 & 51.5 & 23.7 & 28.3 \\
\hline P5-Wadi & $\mathrm{C} 1$ & 73.25 & 5.04 & 1.89 & 0.57 & 1.98 & 3.87 & 4.50 & 0.31 & 0.98 & 0.02 & 0.008 & 56.6 & 32.7 & 46.3 \\
\hline Ahw-Rowis & $\mathrm{C} 2$ & 73.11 & 4.58 & 2.10 & 0.97 & 1.75 & 3.90 & 5.40 & 0.28 & 0.78 & 0.01 & 0.007 & 54.0 & 29.3 & 44.8 \\
\hline P6-Wadi & $\mathrm{C}$ & 59.78 & 5.25 & 15.05 & 0.97 & 3.15 & 2.28 & 2.15 & 0.95 & 0.55 & 0.12 & 0.003 & 69.7 & 40.9 & 49.2 \\
\hline Al-Ghaib & $2 \mathrm{C}$ & 61.25 & 4.94 & 13.17 & 1.03 & 4.16 & 2.04 & 1.75 & 0.79 & 0.65 & 0.13 & 0.004 & 70.8 & 38.3 & 44.3 \\
\hline Al-Gnaito & $3 \mathrm{C}$ & 58.94 & 5.11 & 14.35 & 0.98 & 3.48 & 2.25 & 2.05 & 0.98 & 0.55 & 0.11 & 0.003 & 69.4 & 39.6 & 47.1 \\
\hline (Dam 2) & $4 \mathrm{C}$ & 62.35 & 4.19 & 13.09 & 1.04 & 3.89 & 1.75 & 1.36 & 0.83 & 0.75 & 0.14 & 0.004 & 70.5 & 37.4 & 42.6 \\
\hline & $\mathrm{C}$ & 55.12 & 7.08 & 16.07 & 1.21 & 4.65 & 2.05 & 1.38 & 0.75 & 0.47 & 0.06 & 0.004 & 77.5 & 46.7 & 51.4 \\
\hline P7-Wadi & $\mathrm{Ck}$ & 56.19 & 6.02 & 16.38 & 1.12 & 6.08 & 1.79 & 1.81 & 0.69 & 0.41 & 0.05 & 0.004 & 77.1 & 38.3 & 43.3 \\
\hline Al-Ghaib & $2 \mathrm{C} 1$ & 59.49 & 5.45 & 15.94 & 1.23 & 5.95 & 2.08 & 2.67 & 0.54 & 0.15 & 0.03 & 0.006 & 72.4 & 33.7 & 40.4 \\
\hline (Dam 3) & $2 \mathrm{C} 2$ & 60.08 & 6.38 & 17.05 & 0.95 & 4.49 & 2.04 & 2.45 & 0.25 & 0.31 & 0.04 & 0.003 & 75.8 & 41.5 & 49.4 \\
\hline & $3 \mathrm{C}$ & 59.18 & 6.15 & 16.57 & 0.75 & 5.15 & 1.89 & 2.35 & 0.46 & 0.14 & 0.02 & 0.004 & 76.5 & 39.6 & 46.6 \\
\hline P8-Wadi & $\mathrm{C} 1$ & 63.89 & 7.02 & 1.25 & 3.98 & 5.52 & 4.99 & 0.48 & 1.25 & 0.78 & 0.02 & 0.005 & 58.5 & 39.0 & 40.0 \\
\hline Mareikh & $\mathrm{C} 2$ & 64.31 & 6.94 & 1.19 & 4.06 & 5.03 & 4.95 & 0.41 & 1.31 & 0.91 & 0.01 & 0.005 & 58.4 & 40.0 & 41.0 \\
\hline P9-Wadi & C1 & 72.94 & 7.25 & 0.47 & 0.49 & 0.62 & 3.17 & 5.89 & 1.34 & 0.06 & 0.04 & 0.004 & 69.6 & 42.8 & 65.7 \\
\hline P9-Wadi & $\mathrm{C} 2$ & 73.21 & 6.96 & 0.49 & 0.41 & 0.56 & 3.35 & 4.16 & 1.29 & 0.07 & 0.05 & 0.007 & 67.5 & 46.3 & 64.0 \\
\hline Nasab & $\mathrm{C} 3$ & 73.63 & 7.27 & 0.51 & 0.48 & 0.36 & 3.65 & 3.54 & 1.31 & 0.04 & 0.03 & 0.001 & 66.6 & 49.1 & 64.5 \\
\hline P10-Wadi & $\mathrm{C} 1$ & 71.05 & 8.25 & 3.23 & 1.25 & 0.52 & 3.79 & 5.92 & 0.71 & 0.02 & 0.01 & 0.002 & 68.5 & 44.6 & 65.7 \\
\hline P10-Wadi & $\mathrm{C} 2$ & 72.06 & 9.16 & 3.25 & 1.19 & 0.42 & 3.97 & 6.15 & 0.64 & 0.01 & 0.03 & 0.002 & 69.8 & 46.5 & 67.6 \\
\hline Al-Hamam & $\mathrm{C} 3$ & 71.24 & 8.65 & 3.01 & 1.15 & 0.39 & 3.75 & 6.47 & 0.71 & 0.02 & 0.03 & 0.001 & 69.8 & 44.9 & 67.6 \\
\hline & $\mathrm{C}$ & 59.35 & 14.95 & 9.54 & 2.21 & 1.05 & 2.09 & 3.65 & 0.24 & 0.07 & 0.02 & 0.003 & 87.7 & 68.8 & 82.6 \\
\hline & Cy & 59.16 & 13.37 & 9.65 & 2.32 & 1.06 & 1.98 & 3.45 & 0.26 & 0.06 & 0.02 & 0.004 & 87.1 & 67.3 & 81.5 \\
\hline P11-Wadi & $2 \mathrm{C}$ & 57.65 & 13.05 & 7.26 & 2.15 & 1.24 & 2.71 & 2.87 & 0.19 & 0.05 & 0.03 & 0.001 & 82.8 & 65.7 & 76.8 \\
\hline Zoghra & $3 \mathrm{C} 1$ & 58.25 & 12.25 & 8.01 & 3.15 & 2.08 & 2.64 & 3.05 & 0.38 & 0.03 & 0.01 & 0.005 & 82.3 & 61.2 & 72.2 \\
\hline & $3 \mathrm{C} 2$ & 58.12 & 11.94 & 8.25 & 3.01 & 2.08 & 2.48 & 3.08 & 0.35 & 0.04 & 0.02 & 0.003 & 82.8 & 61.0 & 72.4 \\
\hline P12-Wadi & $\mathrm{C} 1$ & 65.58 & 5.78 & 1.55 & 6.12 & 5.19 & 5.72 & 1.29 & 1.61 & 0.02 & 0.02 & 0.002 & 50.3 & 32.1 & 34.6 \\
\hline Mion & $\mathrm{C} 2$ & 66.25 & 5.82 & 1.23 & 6.35 & 6.05 & 5.56 & 1.15 & 1.49 & 0.02 & 0.03 & 0.002 & 51.1 & 31.3 & 33.4 \\
\hline Maaian & $2 \mathrm{C}$ & 62.15 & 4.25 & 0.88 & 7.28 & 7.12 & 4.85 & 1.46 & 0.98 & 0.01 & 0.04 & 0.001 & 46.7 & 24.0 & 26.2 \\
\hline P13-Wadi & $\mathrm{C}$ & 61.35 & 4.52 & 0.18 & 3.5 & 7.12 & 6.59 & 1.37 & 0.25 & 0.04 & 0.02 & 0.003 & 40.7 & 23.1 & 24.8 \\
\hline Shuli & $2 \mathrm{C}$ & 63.53 & 5.25 & 0.45 & 2.6 & 6.25 & 6.19 & 2.51 & 0.12 & 0.01 & 0.03 & 0.001 & 45.9 & 26.0 & 29.7 \\
\hline P14-Wadi & $\mathrm{C} 1$ & 59.35 & 6.01 & 0.06 & 3.48 & 6.32 & 5.06 & 1.25 & 0.08 & 0.01 & 0.02 & 0.007 & 54.3 & 32.2 & 34.6 \\
\hline P14-Wadi & $2 \mathrm{Cl}$ & 58.65 & 5.06 & 0.14 & 2.15 & 4.25 & 4.43 & 1.03 & 0.12 & 0.03 & 0.01 & 0.005 & 53.3 & 34.3 & 36.8 \\
\hline Abu-Khashab & $2 \mathrm{C} 2$ & 58.25 & 4.98 & 0.16 & 2.65 & 4.65 & 4.34 & 1.05 & 0.14 & 0.04 & 0.01 & 0.005 & 53.4 & 33.2 & 35.6 \\
\hline P15-Wadi & $\mathrm{C} 1$ & 58.32 & 3.06 & 2.45 & 3.47 & 6.26 & 3.95 & 1.79 & 0.95 & 0.29 & 0.12 & 0.004 & 43.7 & 20.3 & 23.1 \\
\hline Um-Ism & $\mathrm{C} 2$ & 60.26 & 3.15 & 3.12 & 3.48 & 6.69 & 4.23 & 1.25 & 0.98 & 0.23 & 0.12 & 0.005 & 42.7 & 20.6 & 22.4 \\
\hline Um-Ism & $\mathrm{C} 3$ & 58.65 & 2.95 & 2.91 & 3.65 & 6.12 & 4.25 & 1.36 & 0.88 & 0.24 & 0.13 & 0.005 & 41.0 & 20.1 & 22.1 \\
\hline & $\mathrm{C}$ & 48.25 & 14.12 & 7.15 & 2.32 & 9.05 & 2.61 & 2.15 & 3.34 & 0.04 & 0.21 & 0.006 & 84.4 & 50.6 & 54.8 \\
\hline P16-Wadi & $\mathrm{Ck}$ & 48.35 & 14.05 & 7.13 & 2.44 & 8.65 & 1.99 & 2.29 & 3.65 & 0.05 & 0.23 & 0.005 & 87.6 & 52.1 & 56.9 \\
\hline Pro-waui & $2 \mathrm{C}$ & 49.36 & 14.35 & 8.31 & 1.35 & 7.94 & 1.92 & 2.08 & 4.45 & 0.07 & 0.18 & 0.001 & 88.2 & 54.6 & 59.3 \\
\hline Dahab's delta & $3 \mathrm{C} 1$ & 50.15 & 13.05 & 9.12 & 1.86 & 8.78 & 1.71 & 1.37 & 2.75 & 0.08 & 0.31 & 0.005 & 88.4 & 52.4 & 55.4 \\
\hline & $3 \mathrm{C} 2$ & 50.35 & 13.12 & 7.08 & 2.11 & 6.89 & 1.68 & 1.33 & 2.89 & 0.09 & 0.32 & 0.004 & 88.6 & 57.0 & 60.5 \\
\hline
\end{tabular}

Explanations: ${ }^{\dagger}$ CPA (chemical proxy of alteration; Buggle et al., 2011), CIA (chemical index of alteration; Nesbitt and Young, 1982), CIW (chemical index of weathering; Harnois, 1988) 
Table (4): Mineral percentage of sediments and mineralogical indices across Wadi Dahab drainage Basin study area

\begin{tabular}{|c|c|c|c|c|c|c|c|c|c|c|c|c|c|c|c|c|c|c|c|c|}
\hline \multirow[t]{2}{*}{ Pedon } & \multicolumn{2}{|c|}{ Light minerals (\%) } & \multirow[t]{2}{*}{$\mathbf{H M}^{\dagger}$} & \multirow[t]{2}{*}{$\mathrm{Opq}^{\ddagger}$} & \multicolumn{13}{|c|}{ Non-opaque minerals ${ }^{\S}$} & \multicolumn{3}{|c|}{$\begin{array}{c}\begin{array}{c}\text { Mineralogical } \\
\text { indices }\end{array} \\
\end{array}$} \\
\hline & Quartz & Feldspar & & & 0 & $\mathbf{H}$ & A & $\mathbf{E}$ & $\mathbf{K}$ & $\mathrm{Zs}_{\mathbf{s}}$ & G & $\mathbf{S}$ & B & M & $T$ & $\mathbf{Z}$ & $\mathbf{R}$ & Gzi & $\mathbf{R Z i}$ & ZTR \\
\hline \multirow{2}{*}{$\begin{array}{l}\text { P1-Wadi } \\
\text { Abu-Gardat }\end{array}$} & 90.75 & 9.25 & 2.15 & 39.2 & 0.05 & 6.78 & 1.09 & 1.25 & 0.35 & 0.04 & 1.23 & 0.15 & 5.02 & 1.25 & 3.25 & 7.64 & 0.55 & 13.9 & 6.7 & 39.9 \\
\hline & $\begin{array}{l}91.68 \\
90.85\end{array}$ & $\begin{array}{l}8.32 \\
9.15\end{array}$ & $\begin{array}{l}3.04 \\
2.56\end{array}$ & 43.6 & 0.19 & $\begin{array}{r}7.65 \\
649\end{array}$ & 0.85 & 0.98 & 0.17 & 0.06 & 2.65 & 0.24 & 6.03 & 1.98 & 4.53 & 8.65 & 0.95 & 23.5 & 9.9 & 40.5 \\
\hline \multirow{3}{*}{$\begin{array}{l}\text { P2-Wadi Al-Gibby } \\
\text { (Dam 1) }\end{array}$} & 96.35 & 3.65 & 4.15 & $\frac{42.0}{48.2}$ & 0.07 & 9.45 & $\frac{1.05}{1.49}$ & 1.07 & $\frac{0.91}{0.35}$ & $\frac{0.04}{0.03}$ & $\frac{1.18}{2.15}$ & $\frac{0.16}{0.14}$ & $\frac{5.05}{4.35}$ & $\frac{1.15}{3.31}$ & $\begin{array}{l}3.65 \\
9.19\end{array}$ & $\frac{7.26}{5.36}$ & $\frac{0.45}{2.25}$ & $\frac{19.7}{28.6}$ & $\frac{5.8}{29.6}$ & $\frac{38.8}{42.9}$ \\
\hline & 95.35 & 4.65 & 3.65 & 46.7 & 0.03 & 8.56 & 0.46 & 0.98 & 0.79 & 0.01 & 1.35 & 0.35 & 6.15 & 4.24 & 8.01 & 3.65 & 1.91 & 27.0 & 34.4 & 37.2 \\
\hline & 93.88 & 6.12 & 3.98 & 45.9 & 0.03 & 8.68 & 0.21 & 0.75 & 0.65 & 0.01 & 1.24 & 0.31 & 6.34 & 5.36 & 7.86 & 4.77 & 1.84 & 20.6 & 27.8 & 38.0 \\
\hline \multirow{3}{*}{ P3-Wadi Hadaba } & 88.55 & 11.45 & 1.25 & 39.3 & 0.02 & 7.56 & 0.69 & 0.15 & 1.15 & 0 & 2.11 & 0.01 & 2.77 & 2.42 & 3.61 & 3.79 & 0.91 & 35.8 & 19.4 & 33.0 \\
\hline & 87.35 & 12.65 & 1.65 & 35.9 & 0.05 & 8.35 & 0.19 & 0.34 & 0.19 & 0 & 1.65 & 0.2 & 3.48 & 3.53 & 4.38 & 4.78 & 1.25 & 25.7 & 20.7 & 36.7 \\
\hline & 89.25 & 10.75 & 1.98 & 38.4 & 0.01 & 9.65 & 0.48 & 0.25 & 0.79 & 0 & 2.41 & 0.3 & 2.44 & 1.51 & 3.45 & 4.19 & 1.08 & 36.5 & 20.5 & $\frac{32.8}{170}$ \\
\hline \multirow{4}{*}{$\begin{array}{l}\text { P4-Wadi } \\
\text { Um-Markha } \\
\text { P5-Wadi Abu- } \\
\text { Rowis }\end{array}$} & 89.75 & 10.25 & 1.25 & 55.5 & 0.02 & 25.65 & 0.65 & 0.08 & 0.15 & 0 & 2.04 & 0.04 & 2.75 & 5.12 & 3.45 & 3.25 & 0.8 & 38.6 & 19.8 & 17.0 \\
\hline & 88.55 & 11.45 & 1.34 & 53.8 & 0.06 & 23.98 & 0.69 & 0.09 & 0.17 & 0 & 1.35 & 0.05 & 3.03 & 6.18 & 4.65 & 4.08 & 0.7 & 24.9 & 14.6 & 20.9 \\
\hline & 89.85 & 10.15 & 1.87 & 44.6 & 0.04 & 22.65 & 1.75 & 0.07 & 0.48 & 0 & 2.54 & 0.03 & 3.71 & 7.08 & 4.65 & 6.65 & 0.07 & 27.6 & 1.04 & 22.9 \\
\hline & 88.45 & 11.55 & 1.35 & 43.2 & 0.08 & 23.24 & 2.83 & 0.11 & 0.85 & 0 & 2.36 & 0.07 & 2.08 & 6.15 & 3.36 & 5.48 & 0.09 & 30.1 & 1.6 & 19.1 \\
\hline \multirow{4}{*}{$\begin{array}{l}\text { P6-Wadi Al-Ghaib } \\
\text { (Dam 2) }\end{array}$} & 97.85 & 2.15 & 4.15 & 45.21 & 0.15 & 11.65 & 0.54 & 1.55 & 1.25 & 0.01 & 1.97 & 0.08 & 6.35 & 6.45 & 5.56 & 12.25 & 3.65 & 13.9 & 23.0 & 41.7 \\
\hline & 96.11 & 3.89 & 5.36 & 43.19 & 0.13 & 10.34 & 0.66 & 0.89 & 0.89 & 0.05 & 2.26 & 0.04 & 7.15 & 5.36 & 5.65 & 13.65 & 4.45 & 14.2 & 24.6 & 46.1 \\
\hline & 98. & 1.67 & 4.25 & 5.09 & 0.15 & 11.73 & 0.41 & 1.42 & 1.18 & 0.01 & 1.89 & 0.08 & 6.35 & 6.15 & 4.25 & 14.25 & 3.89 & 11.7 & 21.4 & 43.3 \\
\hline & 97.25 & 2.75 & 5.65 & 44.36 & 0.16 & 13.43 & 0.27 & 1.31 & 0.87 & 0.02 & 2.35 & 0.01 & 8.35 & 5.62 & 5.36 & 14.98 & 4.07 & 13.6 & 21.4 & 43.0 \\
\hline \multirow{5}{*}{$\begin{array}{l}\text { P7-Wadi Al-Ghaib } \\
\text { (Dam 3) }\end{array}$} & 96.85 & 3.15 & 5.36 & 42.78 & 0.24 & 5.47 & 1.07 & 0.94 & 1.71 & 0.03 & 2.32 & 0.01 & 11.25 & 8.64 & 15.23 & 16.21 & 5.05 & 12.5 & 23.8 & 53.5 \\
\hline & 97.55 & & 5.45 & 42.24 & 0.25 & 5.58 & 1.09 & 1.01 & 1.65 & 0.03 & 2.65 & 0.01 & 10.35 & 9.75 & 15.45 & 17.05 & 4.65 & 13.5 & 21.4 & 53.4 \\
\hline & 97.35 & 2.65 & 6.85 & 43.99 & 0.35 & 4.11 & 0.58 & 1.18 & 1.78 & 0.05 & 1.72 & 0.03 & 12.35 & 10.35 & 14.88 & 14.65 & 3.08 & 10.5 & 17.4 & 50.1 \\
\hline & 97.82 & 2.18 & 7.04 & 44.39 & 0.33 & 3.78 & 0.34 & 1.79 & 1.95 & 0.04 & 1.35 & 0.03 & 12.24 & 10.68 & 16.97 & 13.05 & 3.15 & 9.4 & 19.4 & 50.5 \\
\hline & 98.11 & 1.89 & 6.29 & 49.78 & 0.14 & 5.28 & 1.15 & 0.95 & 0.98 & 0.06 & 2.89 & 0.02 & 10.97 & 8.75 & 15.85 & 11.65 & 5.15 & 19.9 & 30.7 & 51.1 \\
\hline \multirow{2}{*}{ P8-Wadi Mareikh } & 89.95 & 10.05 & 2.23 & 32.91 & 5.08 & 1.25 & 2.35 & 11.24 & 12.15 & 6.25 & 10.25 & 9.25 & 5.25 & 7.25 & 6.45 & 2.86 & 3.48 & 78.2 & 54.9 & 15.4 \\
\hline & 88.78 & 11.22 & 2.14 & 31.47 & 4.65 & 0.98 & 1.85 & 9.15 & 13.65 & 5.15 & 11.45 & 8.19 & 6.41 & 6.17 & 3.45 & 3.47 & 3.98 & 76.7 & 53.4 & 13.9 \\
\hline & 84.85 & 15.15 & 2.48 & 36.8 & 0.83 & 0.26 & 4.65 & 8.39 & 20.65 & 6.25 & 8.89 & 5.72 & 13.65 & 9.31 & 4.65 & 4.25 & 2.36 & 67.7 & 35.7 & 12.6 \\
\hline P9-Wadi Nasab & & & 3.15 & & 0.78 & 0.15 & 2.58 & 10.17 & 21.65 & 5.8 & 8.35 & 6.4 & 14.3 & 8.1 & 5.25 & 2.1 & 3.69 & 79.2 & 62.8 & 12.5 \\
\hline & 84.83 & 15.17 & 2.95 & 31.5 & 0.87 & 0.67 & 4.65 & 11.02 & 19.08 & 7.25 & 10.98 & 5.19 & 17.27 & 7.82 & 3.45 & 3.01 & 2.68 & 78.5 & 47.1 & 9.8 \\
\hline & 88.92 & 11.08 & 3.15 & 42.1 & 1.36 & 5.25 & 1.65 & 0.07 & 5.47 & 1.25 & 1.25 & 4.35 & 13.64 & 2.89 & 4.65 & 10.59 & 3.65 & 10.6 & 25.6 & 34.3 \\
\hline P10-n & & 10. & 4.65 & & 1.14 & 3.47 & 2.37 & 0.06 & 4.25 & 1. & 0.2 & 4. & 14.3 & 3.0 & 2.68 & 8.9 & 4.67 & 2.7 & 34.3 & 32.1 \\
\hline Al-Hamam & & 11.12 & 5.2 & & 1.27 & 2.35 & 1.19 & 0.05 & 5.36 & 1.7 & 1.34 & 5.4 & 14.25 & 3.19 & 1.35 & 9.08 & 3.75 & 12.9 & 29.2 & 28.7 \\
\hline & 96.96 & 3.04 & 7.25 & 48.4 & 0.45 & 1.22 & 3.25 & 1.28 & 1.21 & 3.15 & 2.32 & 1.35 & 4.15 & 6.34 & 11.45 & 12.26 & 9.75 & 15.9 & 44.3 & 57.5 \\
\hline & & & 7.8 & & 0.34 & 1.35 & 2.43 & 1.24 & 1.34 & 2. & 2.15 & 1.64 & 4.35 & 7.1 & 11.12 & 12. & 9.48 & 14.9 & 43.6 & 57.1 \\
\hline P11-Wadi Zoghra & 97.15 & 2. & 9.8 & 46 & 0.57 & 0.37 & 1.18 & 0.88 & 1.72 & 3. & 3.35 & 1.58 & 2.64 & 9.2 & 12.56 & 7.3 & 11.74 & 31.4 & 61.6 & 55.7 \\
\hline & & & & & & 0.69 & 3.58 & 1.91 & 1.48 & 3.8 & 2.78 & 1.21 & 6.8 & 7.2 & 13.45 & 11. & 9.34 & 19.8 & 45.3 & 52.7 \\
\hline & & & 10.67 & 41.2 & 0.69 & 1.56 & 3.45 & 1.89 & 1.43 & 4. & 2.35 & 1.36 & 6.98 & 8.37 & 13.65 & 11.26 & 10.89 & 17.3 & 49.2 & 52.6 \\
\hline & 93.55 & 6.45 & 3.25 & 37.1 & 6.25 & 3.26 & 3.65 & 0.08 & 0.58 & 0.2 & 1.25 & 0.2 & 8.25 & 9.07 & 6.45 & 4.85 & 1.78 & 20.5 & 26.8 & 28.5 \\
\hline P12-Wadi Maaian & 92.54 & & 2.98 & 38 & 4.74 & 4.65 & 2.54 & 0.07 & 1.65 & 0.7 & 1.24 & 0 . & 7.69 & 6. & 5.67 & 3.0 & $1 .($ & 29.2 & 26.6 & 24.8 \\
\hline 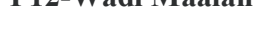 & & & 3.12 & 37.4 & 3.15 & 7.89 & 1.35 & 0.06 & 3.08 & 0.98 & 1.98 & 0. & 7.98 & 8.01 & 4.25 & 4.3 & 1. & 31.5 & 27.4 & 22.8 \\
\hline & 94.75 & 5.25 & 2.98 & 38.5 & 0.48 & 5.24 & 1.65 & 0.04 & 2.25 & 0.1 & 1.25 & 0.4 & 0.3 & 0.16 & 6.45 & 3.09 & 0. & 28.8 & 14.9 & 45.8 \\
\hline P13-Wadi Shuki & & & 2.45 & 33.3 & 0.25 & 6.15 & 1.32 & 0.02 & 1.65 & 0.2 & 0.65 & 0.7 & 0.4 & 0.13 & 3.25 & 5.07 & 0.67 & 11.4 & 11.7 & 43.9 \\
\hline & 93.65 & 6.35 & 3.98 & 45.2 & 2.35 & 7.98 & 4.58 & 1.25 & 3.75 & 0.13 & 1.15 & 0.75 & 0.5 & 0.24 & 8.45 & 3.65 & 1.98 & 24.0 & 35.2 & 38.3 \\
\hline & & & & & 3.45 & 6.65 & 5.08 & 1.34 & 2.95 & 0.1 & 1.46 & 0.3 & 0.8 & 0.2 & 7.65 & 3.7 & 2. & 27.8 & 36.6 & 37.7 \\
\hline Abu-Khashab & 94 & 5.1 & 4.17 & 48 & 3.98 & 7.08 & 6.11 & 0.98 & 1.89 & 0.18 & 1.71 & 0.16 & 0.4 & 0.31 & 7.24 & 4.07 & 2.25 & 29.6 & 35.6 & 37.3 \\
\hline & & & 2.3 & & 3.25 & 10.36 & 5.58 & 0.05 & 0.05 & 0 . & 0.26 & 0.3 & 5.99 & 0.1 & 1.09 & 0.8 & 0.46 & 8.3 & 24.3 & 36.2 \\
\hline & 93.25 & & 1.98 & 58. & 2.63 & 11.65 & 6.83 & 0.07 & 0.06 & 0. & 0.35 & 0.15 & 6.75 & 0.1 & 1.15 & 1.3 & 0. & 9.2 & 20.3 & 21.7 \\
\hline Um-Ism & 94.55 & 5.45 & 2.36 & 56.1 & 2.91 & 13.65 & 7.94 & 0.09 & 0.05 & 0.09 & 0.58 & 0.31 & 5.15 & 0.13 & 1.19 & 0.79 & 0.12 & 6.4 & 42.3 & 13.2 \\
\hline & 98.67 & 1.33 & 8.36 & 31.3 & 0.08 & 0.16 & 0.37 & 1.65 & 0.11 & 1.05 & 3.46 & 1.25 & 11.46 & 6.75 & 15.65 & 13.25 & 6.25 & 20.7 & 32.1 & 57.2 \\
\hline & & 1.45 & 9.15 & 37.1 & 0.02 & 0.19 & 0.37 & 1.89 & 0.75 & 0.3 & 4.09 & 2.31 & 13.86 & 5.6 & 16.85 & 14.65 & 7.69 & 21.8 & 34.4 & 57.1 \\
\hline ađi Danab's & 99.22 & 0.78 & 10.98 & 38.4 & 0.14 & 1.68 & 1.98 & 2.35 & 0.58 & 0.63 & 5.79 & 1.15 & 10.49 & 3.85 & 13.78 & 17.15 & 6.35 & 25.2 & 27.0 & 56.6 \\
\hline & 99.11 & 0.89 & 12.36 & 40.8 & 0.06 & 0.86 & 0.76 & 2.07 & 1.65 & 0.09 & 6.34 & 0.94 & 9.13 & 5.39 & 15.39 & 18.35 & 4.65 & 25.7 & 20.2 & 58.5 \\
\hline & 98.75 & 1.25 & 12.09 & 41.2 & 0.08 & 0.98 & 0.89 & 2.06 & 1.58 & 0.07 & 6.11 & 0.69 & 9.89 & 5.89 & 15.65 & 18.14 & 5.25 & 25.2 & 22.4 & 58.0 \\
\hline
\end{tabular}

Explanations: $\mathbf{H M}$ (heavy mineral concentration); ${ }^{*}$ opq (opaques); ${ }^{\mathbf{O}}$ (olivine), $\mathbf{H}$ (hornblende), A (augite) E
(zircon), R (rutile); 
In Wadi Dahab Basin, the provenance GZi index widely varied from 2.7 in Wadi Al-Hamam to $79.2 \%$ in Wadi Nasab while RZi index ranged $1.04 \%$ in Wadi Abu-Rowis to $62.8 \%$ in Wadi Nasab. The highest values were recorded in Wadi Zoghra's subtributaries (Mareikh and Nasab). The maturity ZTR index exhibited a relatively wide range of values ranging from $6.4 \%$ in Wadi Um-Ism to $58.5 \%$ in Wadi Dahab's delta. The lower values of ZTR index $(<40 \%$ ZTR) suggest that almost all the locations (P1, P2, P3, P4, P5, P6, P8, P9, $\mathrm{P} 10, \mathrm{P} 12, \mathrm{P} 13, \mathrm{P} 14$, and $\mathrm{P} 15)$ contain mineralogically immature sediments except for three locations at the downstram of wadis Al-Ghaib (P7) and Zoghra (P11) as well as Wadi Dahab's delta (P16) which have $>50 \%$ indicates submature sediments.

\section{Soil classification}

All studied pedons were classified from soil orders to the families based primarily on the effect of the soil forming factors on morphological properties and maturity of the sediments according to the American system for soil classification (Soil Survey Staff, 2014a). PSD, light minerals, and soil temperature regime are the main differentiae which are used to distinguish families of studied soils within a subgroup. The taxonomic classification data for the studied pedons are synthesized in Table (5). The spatial distribution and taxonomic classification of soils across the study area are related to the maturity of the sediments and slope position.

The study area sediments belong into Entisols and Aridisols. Sediments from all catenas of the subtributaries as well as Wadi Abu-Khashab and UmIsm tributaries were dominantly classified as Entisols. This is because they lacked to form any diagnostic horizons or soil pedogenesis processes (Tables 2 and 5). Three subgroups of Entisols were identified which are Typic Torriorthents (P1, P2, P12, P13, P14, and P15), Lithic Torriorthents (P3, P4, P5, and P8), and Typic Torripsamments (P6, P9 and P10). Lithic Torriorthents were $<50 \mathrm{~cm}$ to the lithic contact, contained $>350 \mathrm{~g} \mathrm{~kg}^{-}$ ${ }^{1}$ rock fragments, and exhibited no subsurface diagnostic horizon development while pedons of Typic Torriorthents were $>50 \mathrm{~cm}$ deep and pedons of Typic Torripsamments were deep and contained $<350 \mathrm{~g} \mathrm{~kg}^{-1}$ rock fragments (Table 2 ).

In contrast, soils of the downstream of Wadi AlGhaib were classified as Typic Haplocalcids (P7), the soil of Wadi Zoghra bottom (P11) was classified as Typic Haplogypsids, and that of the Wadi Dahab's delta was classified as Typic Haplocalcids (P16). Because of the profound modification by anthropogenic activities through dam construction (Yang et al., 2018), Wadi AlGhaib soils at dam 3 have been considered as an independent unit in soil classification compared to other tributaries of Wadi Al-Ghaib. These soils are classified as Aridisols defined by the presence of calcic and gypsic horizons, with a total minimum thickness of 30$40 \mathrm{~cm}$. The upper layer of P7, receiving same sediments tapped by the dam 3 , is $75 \mathrm{~cm}$ thick and consists of an upper C layer $(35 \mathrm{~cm})$ overlying a $\mathrm{C} 2$ calcic horizon. The upper layer showed weak soil aggregates and a specific Munsell color (Munsell hue of 7.5 YR or yellower; moist value $\leq 4$ and chroma $\leq 2$ ). Similarly, P16 at toeslope of the toposequences has a calcic horizon with the same characteros of P7 at damcontrolled watershed. The calcic horizon has a massive structureless, strongly effervescent with $1 \mathrm{~N} \mathrm{HCl}$ that is higher than that of the upper layer, and yellowishbrown, brown or reddish-brown Fe-Mn mottles or coatings. Calcic horizon is characterized by $\mathrm{CaCO}_{3}$ coating or concretions, by redox-depleted zones in macropores. The presence of the calcic horizon is expressed by the Calcids qualifier. On the other hand, the gypsic horizon was found in P11 of Wadi Zoghra. This qualified this soil to be classified as Typic Haplogypsids subgroup. Furthermore, six families were identified across the study area.

\section{DISCUSSION}

Soil formation is the transformation of the parent material of the soil system into the soil mantle (Targulian and Krasilnikov, 2007). In arid climates, the influence of geological material on particle size distribution (PSD) is expected to be greater in soils poorly developed on steep and rocky areas than in other soils with well-developed genetic horizons (Yang et al., 2018). The lower reaches of the Wadi Dahab and its confluence with the Gulf of Aqaba consist of broad alluvial fans and the delta composed of sediments eroded from a wide variety of geological materials upstream. Jenny's (1941) five soil-forming factors account for most of the differences in soil geochemistry and mineralogy across the Wadi Dahab Basin. These five factors are: (1) parent material, (2) climate expressed here as both precipitations by flooding and temperature effects, (3) topography, (4) time, and (5) organisms. Most of the soil derived from limestone plateau located on the upstream of Wadi Al-Gibby has chemical and mineralogical signatures to the north than to the immediately adjacent soil east and west of the mainstream. The alluvial soil in the downslope of Wadi Dahab Basin is an example of long-distance transport of material $(239 \mathrm{~km})$ in a major drainage system to produce a region of soil composition. Clastic sediments (gravels and sands) represent the important lithologic components in the submarine fan (delta) to the Gulf of Aqaba.

\section{Lithologic discontinuities in studied pedons}

Distinct breaks in the lithology of soils can occur in two ways: geologically-sedimentologically or pedologically (Paton et al., 1995). The contact between two unlike parent materials is called a lithologic discontinuity (LD) (Schaetzl and Anderson, 2005). LDs provide important information on parent material origins and subsequent pathways of soil development (Cámara et al., 2017). They represent zones of change in the lithology of soil parent materials that are interpreted to be primarily lithologic, rather than pedogenic (Schaetzl and Anderson, 2005; Cámara et al., 2017). Abrupt changes in sedimentation were found across Wadi Dahab sediments to indicate the LDs via the grain-size composition of the whole soil, including 
both the fine earth (silt and sand) and the rock fragments. Many pedons in Wadi Dahab Basin have formed in more than one parent material, however, the UV2 values within the most investigated pedons were less than 0.60 , indicating homogeneity of parent materials which are the erroneous results because the pedogenic processes may cause translocation of the clay fraction. By contrast, the UV1 had values greater than 0.6 , indicating multiple parent material. In the same time, this heterogeneity within these pedons was further approved by the vertical distribution of coarse fragments. Therefore, the UV2 of Kowalska et al. (2016) produced erroneous results and failed to reveal LD vertically within soils under study.

The presence of LD in most studied pedons was not a result of standard soil forming processes, but usually the result of geogenesis. To be even more discriminatory, identification of a geologic LD should be based on data from an immobile and slowly weatherable soil fraction (Schaetzl and Anderson, 2005; Portes et al. (2016). Immobile elements used in UV1 of Cremeens and Mokma (1986) are excellent indicators of LDs because they reflect sedimentology better than do mobile, or plasma, and particles $<2 \mu \mathrm{m}$ as used in the UV2 method. Hence, the use of the UV1 method to determine LD constitutes a pioneering approach to LD detection while the UV2 method is the improper method to reflect the real $\mathrm{LD}$ and consequently it is not recommended by this study. Moreover, stone line and coarse fragments abundance vertically within the pedon indicated the presence of an erosional episode and thus can detect a LD. Accordingly, the clay-free basis indices (e.g., UV1 and rock fragments as a morphologic indicator) are recommended by the author to detect a clue to a lithologic change in unlike parent materials.

\section{Assessing weathering intensity}

Assessing the geochemical component and weathering indices can improve our understanding of soil formation and process (Schaetzl and Anderson, 2005). It is often useful to know the degree to which a regolith is weathered. Often, the degree of weathering process parallels degree of soil development and formation mobility (Buggle et al., 2011). Weathering involves gradual progressive morphological, physicochemical, and geochemical alterations of the original parent material and transformation to more stable minerals (Young et al., 2010). Under weathering conditions, the element composition of a given parent material changes (Jeong et al., 2008). The principal assumption in formulating chemical weathering indices is that the behavior of chemical elements is controlled solely by the degree of weathering. The earth alkali elements $\mathrm{Ca}, \mathrm{Na}, \mathrm{Mg}$, and $\mathrm{K}$ are geochemically mobile elements while $\mathrm{Al}, \mathrm{Fe}$, and $\mathrm{Ti}$ are less affected by chemical leaching, and tend to concentrate in weathering products (Yang et al., 2004). These elements can be categorized as soluble cations according to the ionic potential (Reeder et al., 2006). However, solubility does not always mean mobility (Buggle et al., 2011). With increasing radius, the tendency of an ion for being adsorbed on clay minerals is higher and thus, its mobility is reduced (Nesbitt et al., 1980). The earth alkali elements $\mathrm{Ca}$ and $\mathrm{K}$ having a smaller ionic radius, are common in silicate minerals such as plagioclase, pyroxene, amphibole, and biotite, which are susceptible to weathering (Nesbitt et al., 1980; Reeder et al., 2006). Furthermore, the distribution of some elements might be controlled by redox conditions. For this reason, the use of the elements $\mathrm{Fe}$ and $\mathrm{Mn}$ in weathering studies is not recommended. CPA index relies on the principle that $\mathrm{Na}^{+}$is easily released from minerals and mobilized during weathering, whereas $\mathrm{Al}^{3+}$ is retained in the profile, forming secondary clay minerals and/or Aloxides (Buggle et al., 2011). The main host mineral group of $\mathrm{Na}$ and $\mathrm{Al}$ in unweathered protoliths is the feldspar group. Weathering products of this group are clay minerals and as end product under extensive weathering conditions kaolinite $\left(\mathrm{Al}_{2} \mathrm{Si}_{2} \mathrm{O}_{5}\left(\mathrm{OH}_{4}\right)\right)$ or gibbsite $\left(\mathrm{Al}(\mathrm{OH})_{3}\right)$, both aluminous residues (Reeder et al., 2006).

Table (5): Taxonomic classification of the pedons studied in Wadi Dahab Basin, South Sinai, Egypt

\begin{tabular}{lll}
\hline Pedon ID & Order & Family level \\
\hline P1-Wadi Abu-Gardat & Entisols & Sandv-skeletal, siliceous, hvperthermic. Tvpic Torriorthents \\
P2-Wadi Al-Gibby (Dam 1) & Entisols & Sandy-skeletal, siliceous, hyperthermic, Typic Torriorthents \\
P3-Wadi Hadaba & Entisols & Sandy-skeletal, mixed, hyperthermic, Lithic Torriorthents \\
P4-Wadi Um-Markha & Entisols & Sandy-skeletal, mixed, hyperthermic, Lithic Torriorthents \\
P5-Wadi Abu-Rowis & Entisols & Sandy-skeletal, mixed, hyperthermic, Lithic Torriorthents \\
P6-Wadi Al-Ghaib (Dam 2) & Entisols & Sandy, siliceous, hyperthermic, Typic Torripsamments \\
P7-Wadi Al-Ghaib (Dam 3) & Aridisols & Sandy, siliceous, hyperthermic, Typic Haplocalcids \\
P8-Wadi Mareikh & Entisols & Sandy-skeletal, mixed, hyperthermic, Lithic Torriorthents \\
P9-Wadi Nasab & Entisols & Sandy, mixed, hyperthermic, Typic Torripsamments \\
P10-Wadi Al-Hamam & Entisols & Sandy, mixed, hyperthermic, Typic Torripsamments \\
P11-Wadi Zoghra & Aridisols & Sandy, siliceous, hyperthermic, Typic Haplogypsids \\
P12-Wadi Maaian & Entisols & Sandy-skeletal, siliceous, hyperthermic, Typic Torriorthents \\
P13-Wadi Shuki & Entisols & Sandy-skeletal, siliceous, hyperthermic, Typic Torriorthents \\
P14-Wadi Abu-Khashab & Entisols & Sandy-skeletal, siliceous, hyperthermic, Typic Torriorthents \\
P15-Wadi Um-Ism & Entisols & Sandy-skeletal, siliceous, hyperthermic, Typic Torriorthents \\
P16-Wadi Dahab's delta & Aridisols & Sandy, siliceous, hyperthermic, Typic Haplocalcids \\
\hline
\end{tabular}


In the sediments of Wadi Dahab Basin, concentrations of immobile elements are increased in downslope soil compared with upslope sediments while concentrations of mobile elements are reduced, with the exception of $\mathrm{CaO}$ that increased in the calcareous sediments (e.g., Wadi Al-Ghaib and delta). $\mathrm{SiO}_{2}$ concentration shows a continuous decrease with increasing degree of weathering, while $\mathrm{Al}_{2} \mathrm{O}_{3}$ contents are characterized by slight decreases. In a parent material containing carbonate, as in most Wadi Dahab deposits, the mobility of $\mathrm{Ca}$ and $\mathrm{Mg}$ is predominantly controlled by the behavior of calcite and dolomite (Reeder et al., 2006). Applied indices (CIA and CIW) employ the molar content of the silicatic bound $\mathrm{Ca}$, given usually as $\mathrm{CaO}$. A comparison between the values of these indices and the distribution of $\mathrm{CaCO}_{3}$ suggests that in most cases low and high indices and $\mathrm{CaO}$ values were connected with high and low carbonate contents, respectively (Tables 2 and 3 ). This observation confirmed the partly post pedogenetically masked by the dynamics of carbonate. Estimation of silicate $\mathrm{Ca}$ in the calcareous material may lead to biased weathering records using these indices and can be problematic due to interferences of the carbonate dynamics. This would exhibit misleadingly low indices values, compared with CPA, (Table 3) and would also cause an underestimation of the weathering intensity. Consequently, the contribution of the carbonate $\mathrm{Ca}$ to the measured $\mathrm{CaO}$, when dealing with calcareous material may derive erroneous results.

By contrast, all indices of the Na-type (CPA, CIA, and CIW) show a similar trend of low intense weathering in the free-carbonate sediments while only CIA and CIW indices show a different pattern in calcareous sediments (Table 3). The values of CPA vertically within the noncalcareous pedons were close to those of K-free index (CIW) compared to CIA (Table 3 ). These results are in accordance with observations in other weathering studies and theoretical considerations of the element behavior, suggesting that $\mathrm{K}$ release is small compared to the $\mathrm{Na}$ release. This is due to stronger weathering resistance of $\mathrm{K}$ phases such as $\mathrm{K}$ feldspar and due to the fixation of $\mathrm{K}$ on clay minerals (Nesbitt and Young, 1984; Yang et al., 2004; Reeder et al., 2006). Harnois (1988) has pointed out that Kfixation can cause an inconsistent behavior of this element in the weathering environment and thus, he recommended not using $\mathrm{K}$ in weathering indices. Furthermore, the CPA being a K-free index avoids uncertainties due to the determination of $\mathrm{CaO}$ and thus the CPA can be applied more general on calcareous sequences.

Despite the arid climate under which they form, the geochemistry of sediments of dam-controlled watershed of Wadi Al-Ghaib (P6 and P7) provides abundant evidence for chemical weathering (69.4 $77.5 \%$ CPA) due to the flooding water harvesting using the check dams compared with upslope pedons that prone to erosion without dam construction (Yang et al., 2018). Furthermore, P11 and P16 on the downslope landscape of Wadi Zoghra and Wadi Dahab's delta, respectively, shows to be the maximum expression of chemical weathering in study area (82.3 - 88.6\% CPA) indicating moderately to slightly strong chemical weathering. This may be attributed to the stability of these portions on the lower landscapes contributed to facilitate water infiltration, thus favoring conditions for weathering and therefore forming deep weathering profiles of weathered regolith (e.g., P6, P7, P11, and P16). Take into account that sediments of the pedons in the upstream subtributaries are formed from a break or move apart the detached material by mechanical weathering or physical erosion that is driven by stress gradients. These stress gradients may arise from gravitational stress, phase transformations. Physical weathering leads to the breakdown of rocks to smaller grain sizes, ideally without causing geochemical and mineralogical changes during the weathering process (e.g., P1, 2, P3, P4, P5, P8, P9, P10, P12, P13, and P15) with geochemical indices below $50 \%$ indicating no chemical weathering. Most calculated weathering indices indicate that surface soil horizons/layers are more weathered than $\mathrm{Cr}$ horizons. Furthermore, using these indices, the homogeneity of the parent material and its provenance can be easily evaluated via the $\mathrm{Al}_{2} \mathrm{O}_{3}-\mathrm{CaO}+\mathrm{Na}_{2} \mathrm{O}-\mathrm{K}_{2} \mathrm{O}(\mathrm{A}-\mathrm{CN}-\mathrm{K})$ diagram (Nesbitt and Young, 1984). Furthermore, diagenetic effects due to dynamics of secondary carbonate or K-fixation (illitization) are no issue in contrast to other indices (Na-type indices involving $\mathrm{CaO}$ and $\mathrm{K}_{2} \mathrm{O}$ ). Together these results demonstrate that chemical weathering is occurring only at the higher elevations on the damcontrolled watershed of Wadi Al-Ghaib as well as at the lower elevations of the downstream of Wadi Zoghra and the Wadi Dahab's delta.

Therefore, indices relying on $\mathrm{Ca}$ or $\mathrm{K}$ (CIA and CIW) are not expected to reflect the true weathering and leaching intensity of calcareous sediment, owing to postpedogenetic formation of secondary carbonates, as in Wadi Al-Ghaib and Wadi Dahab's delta sediments. Thus, it is advisable to restrict the use of such indices to carbonate-free parent material to avoid the problem that effects of silicate weathering. Accordingly, considering element behavior during weathering or diagenesis, the CPA is proposed as the most appropriate index, particularly in calcareous sediments, for silicate weathering to avoid such uncertainties due to the determination of $\mathrm{CaO}$ in the presence of secondary carbonates. By contrast, other evaluated indices (CIA and CIW) are porposed as the appropriate indices in carbonate-free sediments.

\section{Provenance discrimination}

Based on heavy minerals, an attempt has been carried out to find out their parent rocks provenance (Galovic' and Peh, 2016; Mounteney et al., 2018). Some of the heavy minerals are diagnostic of a particular source rock type such as garnet, kyanite, zoisite, and staurolite for high-rank metamorphic rock; biotite, hornblende, and monazite for acid igneous rock; augite, olivine, and augite for basic igneous rock (Pettijohn et al., 1973). Non-opaque mineral assemblage consists of ultrastable minerals (e.g., zircon, tourmaline, and rutile), stable minerals (e.g., garnet, staurolite, biotite, and monazite), moderately stable minerals (e.g., 
epidote, kyanite, and zoisite), unstable minerals (e.g., hornblende and augite), and very unstable (e.g., olivine) (Pettijohn et al., 1973). Based on these diagnostic criteria, the differences in the heavy mineral assemblages, and lithology along the Wadi Dabab, five types of depositional areas are distinguished, indicating spatial variations in provenance (Fig. 6 and Table 4). These areas are described in detail below.

\section{Depositional area $\mathbf{A}$}

The sediments sampled from Wadi Abu-Gardat (P1), Wadi Al-Gibby (P2), and Wadi Hadaba (P3) are characterized by a moderate concentration in hornblende, biotite, tourmaline, and zircon; low GZi, RZi, and ZTR indices (Table 4 and Fig. 2). These findings suggest that these three wadis have similar source rocks and, therefore, they are assigned to the same depositional area (A). The low stability indices of GZi and RZi indicated the origin of the granitic and plutonic rock. The parent rocks in the Wadi Al-Gibby are probably dominated by limestones, sandstones, and alluvial deposits. Furthermore, diorite and ferruginous sandstone were the dominant lithologies for wadis AbuGardat and Hadaba. The sandstones in the upper slopes of Wadi Al-Gibby are responsible for the majority of the sedimentation for the depositional area A. The ZTR index for most of the studied samples of Wadi AlGhaib's subtributaries lies below 50\% indicating immature sediments due to the geomorphic instability and rapid erosion (Mange and Wright, 2007). Furthermore, the sediments represented by deep soils of P6 located behind check dam 3 are dominated by hornblende, monazite, tourmaline, zircon, and rutile. These minerals preferred to supply recycled ultrastable heavy minerals, resulting in the low concentrations of unstable minerals (e.g., olivine) in this area. Hence, the depositional area A is identified for P1, P2, P3 and P6 and their provenance is mixed from sedimentary and intermediate rocks.

\section{Depositional area $B$}

Sediment samples from wadis Um-Markha (P4) and Abu-Rowis (P5) show high hornblende and monazite levels; low rutile, augite, staurolite, and garnet concentrations with the absence of zoisite; low stability (GZi and RZi) and maturity (ZTR) indices (Table 4). Hence, Pedons 4 and 5 are allocated to the same depositional area (B). The high concentration of hornblende can be interpreted to indicate both the high grade metamorphic and plutonic acid igneous rocks (Galovic' and Peh, 2016) of which the sediments of depositional area B were derived.

Accordingly, two depositional areas (A and B) in the Wadi Al-Ghaib were discriminated which are dominated by sedimentary rocks (e.g., sandstone and limestone) followed by igneous rocks (e.g., granite). Furthermore, the sediments collected from the downstream of Wadi Al-Ghaib behind the check dam 3, represented by $\mathrm{P} 7$, are the function of the two depositional areas (A and B). They highly dominated by stable minerals (e.g., biotite and monazite) to ultrstable minerals (e.g., tourmaline, zircon, and rutile). The information contained in rutile is of prime importance, especially in the study of mature sediments. They have more than 50\% values of ZTR index during the Quaternary stage indicates submature sediments with derivation from ancient sandstone and/or recycled sediment.

\section{Depositional area $\mathbf{C}$}

Sediment samples from Wadi Zoghra and its subtributaries (P8, P9, P10 and P11) showed much higher heavy minerals concentration from unstable to ultrastable across the gradient slope (Table 4). Mareikh and Nasab were characterized by high GZi and RZi provenance indices and dominated by kyanite, garnet, epidote, staurolite, and zoisite, compared with Wadi Al-Hamam, indicative of crystalline metamorphic rocks and highly altered igneous rock. Garnet is assumed to have been derived from acid igneous and metamorphic rocks, particularly crystalline gneisses and schists (Mange and Wright, 2007). Staurolite may have been derived from medium to high-grade metamorphic rocks such as schists and gneisses as in Wadi Mareikh. The presence of combined staurolite, kyanite, and garnet suggests a provenance comprising metamorphic rocks of greenschist to amphibolite facies (Mounteney et al., 2018). In contrast, the heavy minerals assemblages in sediments of Wadi Zoghra bottom were dominated by biotite, zircon, tourmaline, rutile, and monazite besides those minerals found in wadis Monazite could be derived from granitic and pegmatitic rocks. Sediments of Mareikh and Nasab reflected their mixed sources from the basic igneous, gneisses/granites, and highgrade metamorphic rocks.

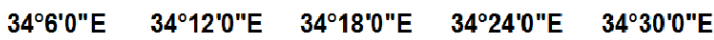

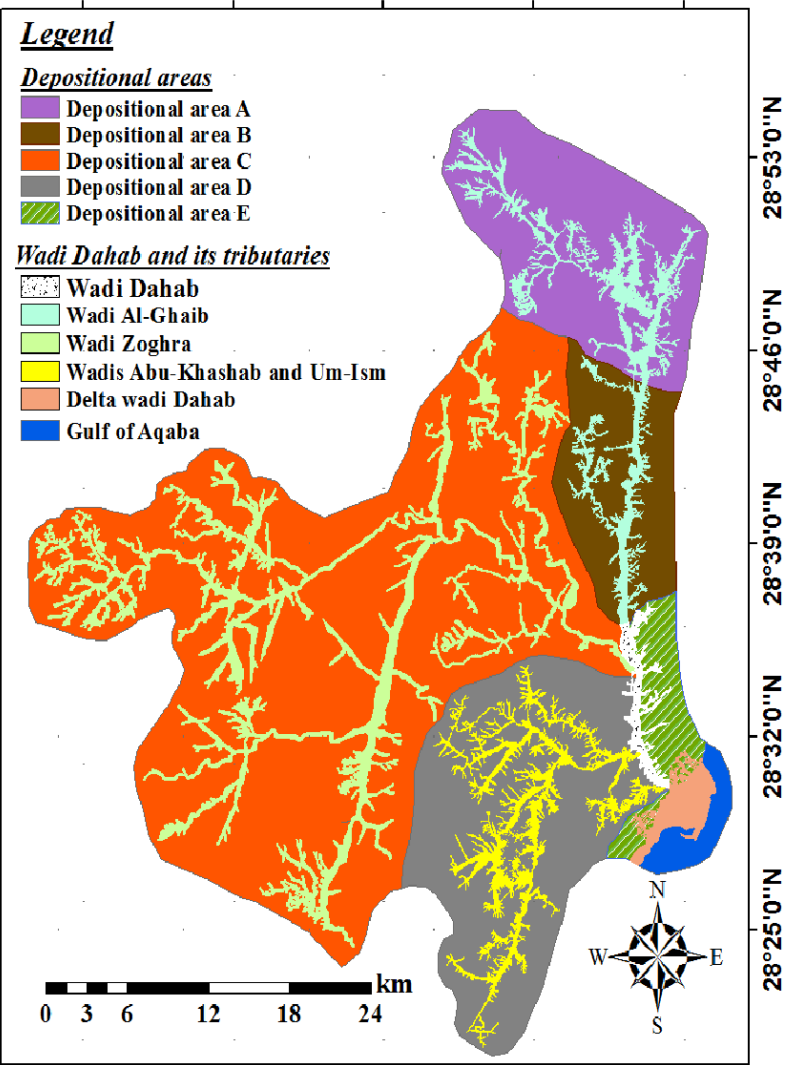

Fig. (6): Discrimination of depositional areas in Wadi Dahab Basin 


\section{Depositional area D}

Wadi Abu-Khashab and its subtributaries have high concentrations of tourmaline, biotite, hornblende, olivine, and augite (Table 4). The presence of these minerals reflects the plutonic igneous rocks, pegmatites, ultramafic varieties, and in intermediate to acidic granitoid rocks (Galovic' and Peh, 2016). Furthermore, the sediment from Wadi Um-Ism has correspondingly increased concentrations of hornblende, augite, and biotite, which are indicative for intermediate rocks (e.g., Neo-proterozoic diorite and andesite). Augite is widespread in various ultramafic and intermediate igneous rock types (Mange and Maurer, 1992). Accordingly, the heavy mineral composition of Wadi Abu-Khashab sediments is similar to those sediments of Wadi Um-Usm. Hence, the provenance for depositional area $\mathrm{D}$ is for these wadis.

\section{Depositional area $\mathbf{E}$}

Although depositional area $\mathrm{E}$ is represented by only diorite rocks (Fig. 1), the provenance of Wadi Dahab's delta sediments is largely mixed. P16-Wadi Dahab's delta is the sedimentary collector as a function of the five depositional areas (A, B, C, D and E) (Fig. $6)$. Its heavy minerals were derived from several distinct rock types and reflected the five depositional areas. They are dominated by the ultra-stable phases zircon, tourmaline, and rutile with stable biotite, garnet, and monazite. Less stable accessories are epidote, augite, hornblende, and kyanite. The sediments of the Dahab's delta were deposited after very long distance $(239 \mathrm{~km})$ (Table 1) from upslope to downslope.

This study demonstrated that the lithology along Wadi streams between the upper and lower reaches have different signatures, which is the main control on the patterns of deposition. The geological formation with their associated rocks played a major role in the contribution of the composition of the heavy mineral in Wadi Dahab Basin. The majority of the sediments of Wadi Dahab's delta were originated from combined weathered sandstone, diorite, and granites, and the minority of sediments were from gabbro and metamorphic rocks. These findings suggest that the sediments in the Wadi Dahab's delta were mainly derived from sedimentary and igneous rocks while the metamorphic rocks contributed only the sediments of Wadi Zoghra and its subtributaries. Sediments of the Cambrian sandstone (Fig. 1), probably sourced from the northern plateau through Wadi Al-Gibby, were deposited after moderate distance transportation $(62 \mathrm{~km})$ through Wadi Al-Ghaib and its subtributaries (Table 1). The mainstream of Wadi Al-Ghaib has been regulated by dams. These dams decreased the annual sediment discharge from Wadi Al-Ghaib to the Wadi Dahab's delta controlled the weathering, erosion, and heavy minerals contribution. Furthermore, such information can help us to protect the ecology and environment of the Wadi Dahab Basin.

\section{Sediment maturity and soil taxa}

The overall geochemistry and mineralogy results allow evaluation of the possible parent materials for Wadi Dahab Basin soils. According to the ZTR index values, the submature sediments of study area were ranked in this order: P16-Wadi Dahab's delta (56.6 $58.5 \%)>$ P11-Wadi Zoghra bottom (52.6 - 57.1\%) > P7-Wadi Al-Ghaib downstream (50.1 - 53.5\%) showing a dramatically decreasing trend from downslope to upslope (Table 4). The immature sediments were originally deposited at the highest elevations and washed away before the landscape became sufficiently stable for pedogenesis. Most studied pedons at upper landscape positions are immature sediments and the youngest at least stable surfaces of the catenas represented by P1, P2, P3, P4, P5, P6, P8, P9, P10, P12, $\mathrm{P} 13, \mathrm{P} 14$ and $\mathrm{P} 15$. These sediments were classified as Entisols. Their sediments tend to be comparatively thin, relatively dry and weak in chemical weathering. This is clear in upper subtributaries which are narrow, where precipitation totals during flash flooding are high or where the soil is slowly permeable. Any of these situations facilitate runoff which is antagonistic to pedogenesis (Yang et al., 2018).

In contrast, the soil forming processes at stable locations within P7, P11 and P16 were associated with secondary calcium carbonate or gypsum enriched which are the diagnostic horizons for Calcids (P7 and P16) or Gypsids (P11), respectively. The lime content may be due to the transformation of primary lime inherited from parent material and therefore an accumulation of secondary lime. The dam construction in the downstream of Wadi Al-Ghaib (P7) made the soil surface more stable which encouraged soil development to proceed downward into the sediment in the absence of erosion. Furthermore, Wadi Zoghra downstream (P11) and Wadi Dahab's delta (P16) had the higher maturity values due to the long distances (111 - $239 \mathrm{~km})$ from the provenance and stability of soil surface with minimal erosion (Table 1). Wide streams with low slopes under dam-controlled watersheds may be the most stable landscape, since water is unlikely to run off (Fielding et al., 2018). The stability geomorphic surface of the landscape is dominated more by chemical weathering (Table 3 ) than by physical weathering and erosion. Most of the water that falls on these sediments infiltrated vertically, leading to wetter soils, thicker regolith $(210 \mathrm{~cm})$ and better horizonation (Ck) (Fig. 5h) than immature sediments at upslope. Sediment on downslope at the delta tends to be finer-textured (Table 2) than material upslope because slope wash processes transport the finer material farther. Accordingly, the submature pedons were classified as Aridisols while immature sediments were classified as Entisols.

\section{CONCLUSION}

The comprehensive investigations of soil morphology, physicochemical, geochemical, mineralogical composition, focused on the sediments of Wadi Dahab Basin at southeastern Sinai of Egypt, have been performed with the purpose of soil formation and taxonomy studies. Four tributaries and their ten subtributaries were identified and mapped across the slope gradient (1335 - 9 m) of Wadi Dahab Basin. The tributaries, from the north to the south, are Al-Ghaib, Zoghra, Abu-Khashab, and Wadi Um-Ism. Pedons from 
subtributaries catenas are formed on colluvial deposits, shallow or moderate deep, gravelly and coarse sand in texture, and characterized by low heavy minerals percentage. By contrast, pedons from downslope of the tributaries and Dahab's delta are developed on sequences of alluvial deposits, deep to very deep, coarse sandy loam to sandy clay loam, and characterized by high heavy minerals percentage.

The investigations have concluded that the Wadi Al-Ghaib and its subtributaries (e.g., Wadi Al-Gibby and Wadi Abu-Gardat) are the dominant control on the calcareous and ferruginous parent materials. In Dahab Basin, parent material is heterogeneous due to the nature of the sedimentary deposits (e.g., colluvial, aeolian, and alluvial deposits) which approved by the uniformity value index (UV1) and rock fragments ( $>$ $2 \mathrm{~mm}$ ) content within the pedons. By contrast, another uniformity index (UV2) which based on combined soil separates (sand, silt, and clay) failed to reveal the presence of LDs between the pedon layers that are already multiple parent materials. This may be ascribed to the clay fraction is pedologically mobile than sand subfractions. In this paper, LD detection method based on the vertical distribution of rock fragments within a pedon as a morphologic indicator, with the aid of clayfree sand separates indices, is presented and by which the heterogeneous nature of the soil has been confirmed.

Commonly applied weathering indices based on geochemical data involving CPA, CIA, and CIW were calculated and evaluated. The results found that the CIA and CIW indices are relatively sensitive to calcareous parent material due to interferences of the carbonate dynamics with silicate $\mathrm{Ca}(\mathrm{CaO})$. To overcome such uncertainties, the CPA (Ca-free) index is proposed as a more appropriate geochemical proxy of silicate weathering for calcareous sediments, while other Natype indices (CIA and CIW) are appropriate for freecarbonates soils. The pedons at upslope have lower CPA values than those of downslope, indicated that the weathering intensity increases horizontally across the toposequence and vertically upwards within pedons. The spatial distribution of heavy minerals in the sediments of Wadi Dahab Basin were studied and five types of depositional areas were distinguished. The majority of Wadi Dahab's delta sediments were originated from a mixture of weathered sandstone, diorite, and granites, and the minority were from gabbro and metamorphic rocks. Furthermore, the maturity of the sediments was measured by ZTR index. Pedons at upslope were immature sediments and classified as Psamments or Orthents, which could be attributed to the geomorphic instability, not allowing sufficient time to develop further. However, pedons from the downslopes of Wadi Al-Ghaib, Wadi Zoghra, and Wadi Dahab's delta were submature sediments and classified as Calcids or Gypsids due to higher weathering intensity, the long-distance transport, and calcic or gypsic horizons formation. Furthermore, six families were identified across the study area. Four families belong to Entisols as in upslope sediments while two families belong to Aridisols as in most downslope sediments.
The study demonstrated that the geochemical characteristics are well correlated with that of mineralogical data across the toposequence, indicating same provenance. The content of heavy minerals and geochemical oxides in most studied pedons followed the LD set, indicating new approaches for detecting LDs. The use of a variety of LD indices constituted a comprehensive approach to the evaluation of the LD, which allows a consistent and straightforward understanding of the pedon heterogeneity. The current study has further implications for understanding landscape geomorphic stability across the span of slope positions. Furthermore, the heavy mineral suites are not only controlled by provenance, but also affected by the source area weathering, geomorphic stability, length of transportation, and post-depositional alteration.

\section{REFERENCES}

Badawy, A. and F. Horvath (1999). The Sinai subplate and tectonic evolution of the northern Red Sea region. J. Geodynamics, 27: 433-450.

Buggle, B., B. Glaser, U. Hambach, N. Gerasimenko and S. Marković (2011). An evaluation of geochemical weathering indices in loessepaleosol studies. Quat. Int., 240: 12-21.

Cámara, J., V. Gómez-Miguel and M. A. Martín (2017). Lithologic control on soil texture heterogeneity. Geoderma, 287: 157-163.

Cremeens, D. L. and D. L. Mokma (1986). Argillic horizon expression and classification in the soils of two Michigan hydrosequences. Soil Sci. Soc. Am. J., 50: 1002-1007.

Darmody, R. G., C. E. Thorn and C. E. Allen (2005). Chemical weathering and boulder mantles, Kärkevagge, Swedish Lapland. Geomorphology, 67: 159-170.

Düzgören-Aydin, N. S., A. Aydin and J. Malpas (2002). Re-assessment of chemical weathering indices: case study of pyroclastic rocks of Hong Kong. Eng. Geol., 63: 99-119.

FAO (2006). Guidelines for Soil Description. fourth ed., pp. 1-98 Rome.

Fielding, C. R., J. Alexander and J. P. Allen (2018). The role of discharge variability in the formation and preservation of alluvial sediment bodies. Sediment. Geol., 365: 1-20

Galovic', L. and Z. Peh (2016). Mineralogical discrimination of the pleistocene loess/paleosol sections in Srijem and Baranja, Croatia. Aeolian Res., 21: 151-162

Geological Survey of Egypt (1994). Geological Map of Sinai, Arab Republic of Egypt (Sheet No. 1). Scale 1: 250.000. Gupta, B. L., 1999: Engineering Hydrology. $3^{\text {rd }}$ Ed. Runoff., 46-56.

Giosan, L., J. Syvitski, S. Constantinescu and J. Day (2014). Protect the world's deltas. Nature, 516: 31-33 (doi: 10.1038/516031a).

Harnois, L. (1988). The CIW of weathering: a new chemical index of weathering. Sediment. Geol., 55: 319-322

Hubert, J. F. (1962). A zircon-tourmaline-rutile maturity index and independence of composition of 
heavy mineral assemblages with gross composition and texture of sandstones. J. Sediment. Petrol., 32: 440-450.

Issawi, B., R. Osman, M. Francis, M. El Hinnawi, Y. El Bagori, A. Mazhar and S. Labib (1998). Contributions to the geology of East Sinai. Annals Geol. Surv. Egypt, XXI: 55-88.

Jenny, H. (1941). Factors of Soil Formation. McGrawHill Book Company, Inc., New York, New York, USA (281 pp.).

Jeong, G. Y., S. Hillier and R. A. Kemp (2008). Quantitative bulk and single particle mineralogy of a thick Chinese loessepaleosol section: implications for loess provenance and weathering. Quat. Int., 27: 1271-1287.

Kowalska, J., R. Mazurek, M. Gasiorek, M. Setlak, T. Zaleski and J. Waroszewski (2016). Soil pollution indices conditioned by medieval metallurgical activity - A case study from Krakow (Poland). Environ. Pollut., 218: 10231036.

Mange, M. A. and H. F. W. Maurer (1992). Heavy minerals in Colour. Chapman and Hall, London, pp. 147.

Mange, M.A. and D. T. Wright (2007). Heavy Minerals in Use. Developments in Sedimentology, 58, Elsevier, Amsterdam, pp. 1328.

Morton, A. C. and C. R. Hallsworth (1994). Identifying provenance-specific features of detrital heavy mineral assemblages in sandstones. Sediment. Geol., 90(3-4): 241-256.

Mounteney, I., A. K. Burton, A.R. Farrant, M. J. Watts, S. J. Kemp and J. M. Cook (2018). Heavy mineral analysis by ICP-AES a tool to aid sediment provenancing. J.Geochem. Explor., 184: 1-10.

Nechaev, V. P. and W. C. Isphording (1993). Heavymineral assemblages of continental margin as indicators of plate-tectonic environments. J. Sediment. Petrol., 63: 1110-1117.

Nesbitt, H. W. and G. M. Young (1982). Early Proterozoic climates and plate motions inferred from major element chemistry of luttites. Nature, 291: 715-717.

Nesbitt, H. W. and G. M. Young (1984). Prediction of some weathering trends of plutonic and volcanic rocks based on thermodynamic and kinetic considerations. Geochimica et Cosmochimica Acta, 48: 1523-1534

Nesbitt, H. W., G. Markovics and R. C. Price (1980). Chemical processes affecting alkalis and alkaline earths during continental weathering. Geochimica et Cosmochimica Acta, 44: 16591666.

Pettijohn, F. J., P. E. Potter and R. Siever (1973). Sand and Sandstones (New York: Springer-Verlag), $618 \mathrm{p}$.

Portes, R. C., D. N. Spinola, J. S. Reis, J. C. Ker, L. M., Costa, E. I. Filho, P. Kühn and C. E. Schaefer (2016). Pedogenesis across a climatic gradient in tropical high mountains, Cordillera Blanca Peruvian Andes. Catena, 147: 441-452.
Reeder, S., H. Taylor, R. A. Shaw and A. Demetriades (2006). Introduction to the chemistry and geochemistry of the elements. In: Tarvainen, T., de Vos, M. (Eds.), Geochemical Atlas of Europe. Part 2. Interpretation of Geochemical Maps, Additional Tables, Figures, Maps, and Related Publications. Geological Survey of Finland, Espoo, pp. 48-429.

Salem, M. (2007). Geological Studies on Submarine Prolongation of Wadi Watir Alluvial Fan in the Gulf of Aqaba, Sinai, Egypt. ISESCO Science and Technology Vision, 3(4): 33-42.

Schaetzl, R. J. and S. Anderson (2005). Soils: Genesis and Geomorphology. Cambridge University Press, Cambridge, p. 817.

Schoeneberger, P. J., D. A. Wysocki, E. C. Benham and Soil Survey Staff (2012). Field book for describing and sampling soils. Version 3.0. Natural Resources Conservation Service, National Soil Survey Center, Lincoln, NE.

Sheldon, N. D., G. J. Retallack and S. Tanaka (2002). Geochemical climofunctions from North American soils and application to paleosols across the Eocene-Oligocene boundary in Oregon. J. Geol., 110: 687-696.

Sheldrick, B. H. and C. Wang (1993). Particle size distribution. p. 499-511. In M.R. Carter (ed.) Soil sampling and methods of analysis. Lewis Publ., Boca Raton, FL.

Soil Science Division Staff (2017). Soil Survey Manual. United States Department of Agriculture (USDA), Agriculture Handbook No. 18. Natural Resources Conservation Service, Washington, D.C.

Soil Survey Staff (2014a). Keys to Soil Taxonomy. 12th ed. USDA-Natural Resources Conservation Service, Washington, DC.

Soil Survey Staff (2014b). Kellogg Soil Survey Laboratory methods manual. Soil Survey Investigations. Report No. 42, version 5.0. R. Burt and Soil Survey Staff (eds.). Washington DC: U.S. Department of Agriculture-Natural Resources Conservation Service.

Targulian, V. O. and P. V. Krasilnikov (2007). Soil system and pedogenic processes: selforganization, time scales, and environmental significance. Catena, 71: 373-381.

von Blanckenburg, F. (2005). The control mechanisms of erosion and weathering at Basin scale from cosmogenic nuclides in river sediment. Earth Planet. Sci. Lett., 237: 462-479. http://dx.doi.org/10.1016/j.epsl.2005.06.030.

Walter, N. F., G. R. Hallberg and T. F. Fenton (1978). Particle-size analysis by the Iowa State University Soil Survey Laboratory, p. 61-74. In Hallberg G.R. (ed.) Standard procedures for evaluation of Quaternary materials in Iowa. Iowa Geological Survey Technical Information Series Number 8, Iowa City, Iowa.

Waroszewski, J., M. Egli, C. Kabala, J. Kierczak and D. Brandova (2016). Mass fluxes and clay mineral formation in soils developed on slope deposits of the Kowarski Grzbiet (Karkonosze 
Mountains, Czech Republic/Poland). Geoderma, 264: 363-378.

Waroszewski, J., M. Malkiewicz, R. Mazurek, B. Labaz, P. Jezierski and C. Kabala (2015). Lithological discontinuities in Podzols developed from sandstone cover beds in the Stolowe Mountains (Poland). Catena, 126: 11-19.

Woodruff, L., W. F. Cannon, D. B. Smith and F. Solano (2015). The distribution of selected elements and minerals in soil of the conterminous United States. J. Geochem. Explor., 154: 49-60
Yang, H. F., S. L. Yang, K. H. Xu, J. D. Milliman, H. Wang, Z. Yang, Z. Chen and C. Y. Zhang (2018). Human impacts on sediment in the Yangtze River: A review and new perspectives. Global and Planetary Change, 162: 8-17.

Yang, S. Y., C. X. Li, D. Y. Yang and X. S. Li (2004). Chemical weathering of the loess deposits in the lower Changjiang Valley, China, and paleoclimatic implications. Quat. Int., 117: 2734.

\section{تكوين وتصنيف أراضى بعض روافد وادى دهب، جنوب سيناء، مصر \\ عادل عبد الحميد علوان خليل \\ قسم البيدولوجى، شعبة مصادر المياه و الأراضي الصحر اوية، مركز بحوث الصحر اءو، القاهرة، رقم بريدي سلrVor}

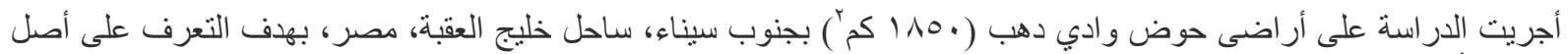

تكوين وتصنيف أر اضى رو افده من خلال الدر اسة الموروفولوجية، الطبيعية (التوزيع الحجمى للحبيبات)، الجيوكيميائية ( ( Fe $\mathrm{O}_{3}, \mathrm{MgO}, \mathrm{CaO}, \mathrm{Na}_{2} \mathrm{O}, \mathrm{K}_{2} \mathrm{O}, \mathrm{TiO}_{2}, \mathrm{and} \mathrm{P}_{2} \mathrm{O}_{5}$ 7 ا قطاع أرضى مُمثل لكافة رو افد حوض الو ادي المدروس. تم التعرف على أربعة رو افد رئيسية (main tributaries) لحوض وض و ادي دهي دهب

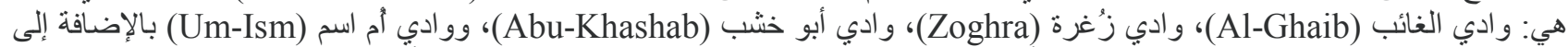

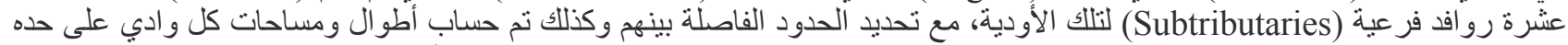

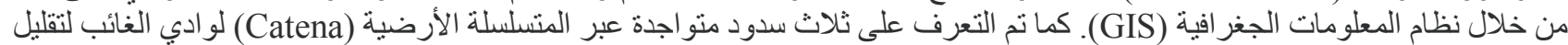

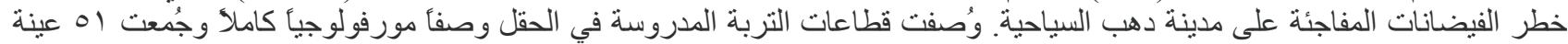

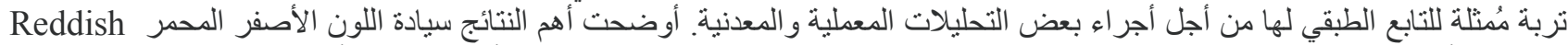

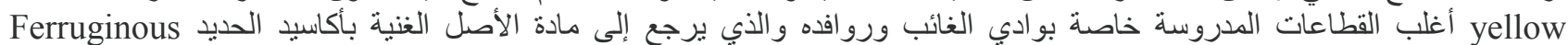

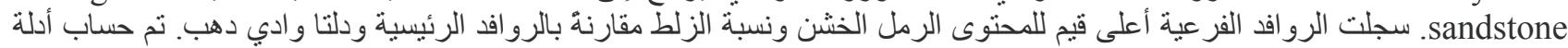

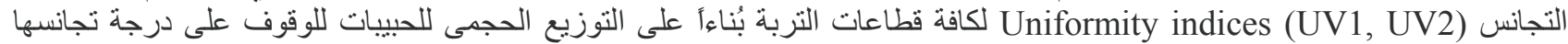

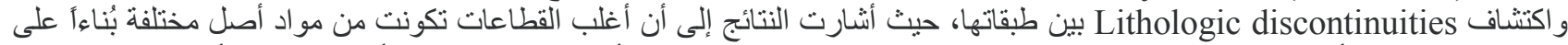

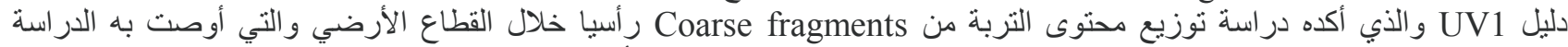

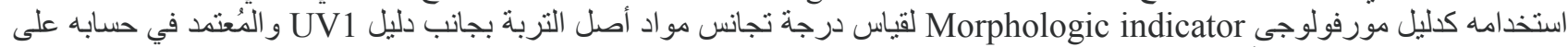

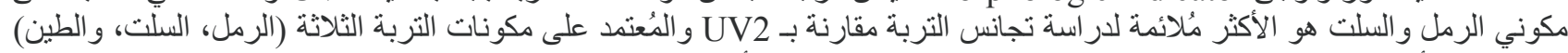

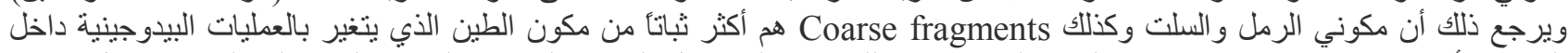

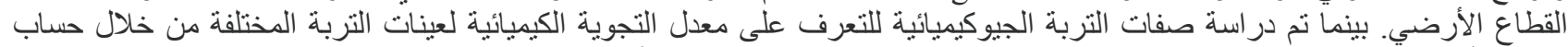

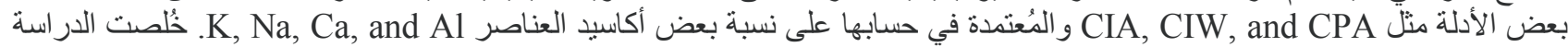

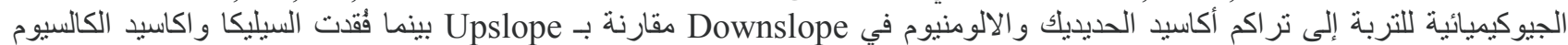

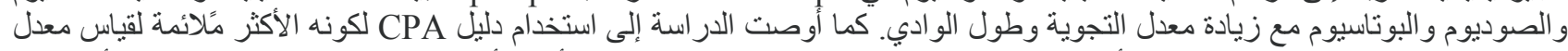

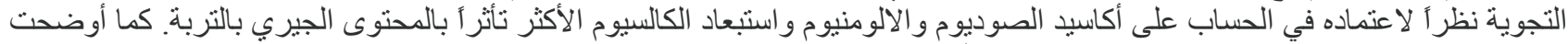

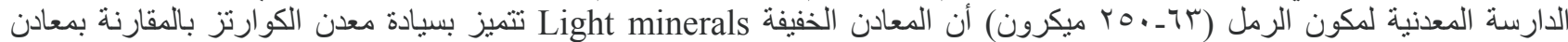

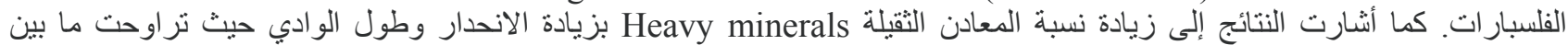

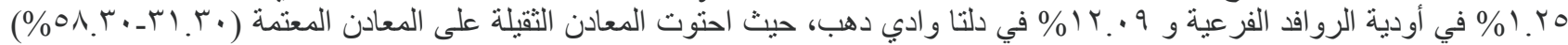

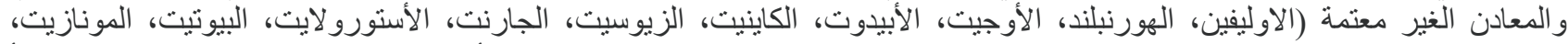

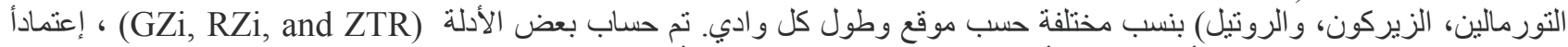

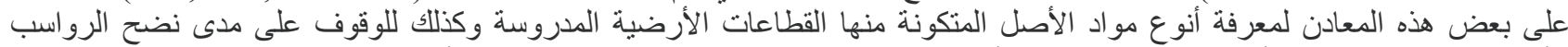

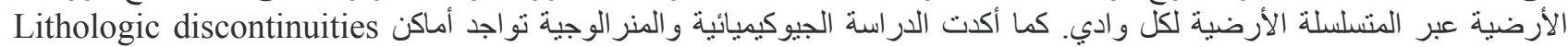

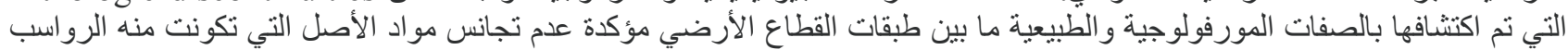

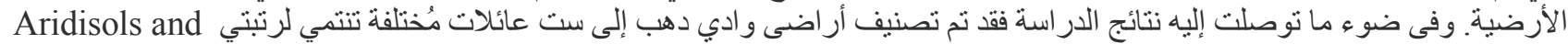

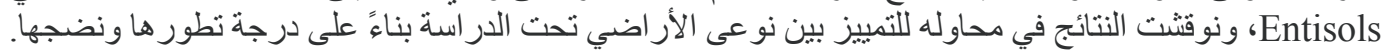

